\title{
Social Media Marketing and Luxury Consumption: A Literature Review
}

\author{
Giuseppe Colella ${ }^{1}$, Cesare Amatulli ${ }^{1} \&$ Maria Pilar Martinez-Ruiz ${ }^{2}$ \\ ${ }^{1}$ Ionian Department of Mediterranean Legal and Economic Systems, University of Bari - Aldo Moro, Taranto, \\ Italy \\ ${ }^{2}$ Department of Business Administration, University of Castilla-La Mancha, Albacete, Spain \\ Correspondence: Giuseppe Colella, Ionian Department of Mediterranean Legal and Economic Systems, \\ University of Bari - Aldo Moro, Taranto, TA., 74121, Italy. E-mail: giuseppe.colella@uniba.it
}

Received: August 1, 2019 Accepted: August 28, 2019 Online Published: September 29, 2019

doi:10.5539/ijms.v11n4p30 URL: https://doi.org/10.5539/ijms.v11n4p30

\begin{abstract}
People and companies worldwide are by now involved and attached to web 2.0 technologies and in particular to social media platforms. In this context, these digital technologies and social media have modified and improved the way to communicate and collaborate between companies and customers in all sectors through by implementing effective interaction mechanisms. However, the approach to social media and digital technologies in sectors such as luxury has been slower. Therefore, the main aim of this study is firstly to systematically examine and review the current studies conducted on the related area of social media and luxury marketing. Secondly, in addition to providing an overview of the main themes and trends covered by the relevant literature, this review has focused on the consumption of luxury and the dual dimension that it can take in a social media context. Third, a systematic review of the literature on academic research on social media marketing in luxury brands was conducted to collect, examine and synthesize the reactive studies. This review also provided important insights on social media marketing in luxury brands and key research topics were classified into three insights, on consumer behavior, brand awareness and advertising activities in a social media context. Therefore, this study, for both academics and marketer manager, could represent a solid theoretical basis for empirical studies on the phenomenon of social media marketing in the field of luxury marketing and luxury brands.
\end{abstract}

Keywords: externalised luxury, internalized luxury, luxury marketing, luxury brands, luxury consumption, social media, social media marketing

\section{Introduction}

The era of digitalisation and the development of social networks are radically changing traditional communication paradigms, influencing the way companies communicate and, more importantly, interact with customers (Essamri, McKechnie, \& Winklhofer, 2019; Gielens \& Steenkamp, 2019). In particular, such an evolution could be summarized by the following changes: a) overcoming unidirectional communication and a greater capacity for direct listening to consumers (Gurău, 2008; Key \& Czaplewski, 2017; Li \& Bernoff, 2008); b) perfect compliance with the specific needs of stakeholders through the co-creation of content between companies and users (Koivisto \& Mattila, 2018; Ozuem, Howell, \& Lancaster, 2008; Truong, McColl, \& Kitchen, 2010); and c) greater forms of interaction among companies and consumers that are less expensive than those possible with traditional media (Vendemia, 2017). Interestingly, such changes have consolidated the transition from a linear communication model - based on the stimulus-response logic, where we have a sender and a receiver, thus constituting a "static" relationship - to a reticular communication model, in which the architecture of the relationship radically changes because of digitization (Royle \& Laing, 2014). It becomes more interactive and based on a plurality of subjects and means (Hoffman \& Novak, 1996; Kohli, Suri, \& Kapoor 2015; Pastore \& Vernuccio, 2008; Vernuccio \& Ceccotti, 2015). Therefore, such a transition tends to influence consumers' behaviour and their approach to new technologies (Alalwan, Rana, Algharabat, \& Tarhini, 2016a; Alalwan, Rana, Dwivedi, \& Algharabat, 2017).

With the digitization and development of social networks, the concept of marketing itself is changing. Indeed, marketing paradigms have shifted from the concept of 'Marketing 2.0', oriented exclusively to consumers and based on unidirectional logic, to the concept of 'Marketing 4.0', where the development of digital technologies is 
the main driver (Kotler, Kartajaya, \& Setawan, 2010; Kotler, Kartajaya, \& Setawan, 2017). To illustrate this transition, a change in the conception of the figure of the consumer is considered. Indeed, the figure of the consumer is implicitly assumed a passive target for marketing campaigns on the part of companies. Thus, given the limited direct and continuous contact with them (Jiménez-Zarco, Rospigliosi, Martínez-Ruiz, \& Izquierdo-Yusta, 2019) and the constant evolution of technologies, an incremental change is witnessed in the levels of interaction with consumers both in time and space (Yeh, Wang, \& Yiehal, 2016), becoming active targets for marketing campaigns.

In this evolving context, in which digital is changing the way we communicate marketing, an important distinction to consider is the one between social networks and social media. The work of Alalwan et al. (2017) sheds light on this distinction and on some definitions introduced by other authors (Filo, Lock, \& Karg, 2015; Wells, 2011). Social networks are web communities of persons with common interests and, according to Wells (2011), these web communities use social media as a means to interact directly with other persons, thus creating a real relationship with them. Concerning social media platforms, instead, Kaplan and Haenlein (2010) claim these are 'tools and applications based on the ideologies and technologies typical of Web 2.0 that allow users to create and exchange contents' (p. 61). Social media, moreover, is a new multimedia technology that adapts the interactions between and co-creation of content among multiple users (Alalwan et al., 2017; Filo et al., 2015). Therefore, in light of the change to the marketing paradigm, social media today represents an important communication channel for users, as it allows them to acquire online processes through well-organised digital platforms (Alalwan et al., 2017; Arrigo, 2018; Kaplan \& Haenlein, 2010). In addition, if social networks can be means of interaction between companies and users, social media also offers the possibility of co-creating content with companies.

In this context, the increasing use of social media has led to the birth of a new era of communication, both for companies and for users (Gallaugher \& Ransbotham, 2010; Patel, 2013). The possibility of co-creating content with companies has dictated the beginnings of a new era of the web, that of Web 3.0. It is based on a big data analysis of these platforms, also known as the semantic web, and which includes such activities as virtual shopping and intelligent research (Filo et al., 2015; Gallaugher \& Ransbotham, 2010; Patel, 2013; Tavakoli \& Wijesinghe, 2019). Therefore, nowadays, social media is considered among the digital communication tools and techniques most used by marketing managers in defining a brand strategy online. This is because it represents platforms designed to facilitate interaction and collaboration among users and companies to encourage the sharing of content by both parties (Godey et al., 2016; Kelly, Kerr, \& Drennan, 2010; Richeter \& Koch, 2007).

Among the most widespread virtual communities that allow the constant development of interactions between users and companies that play a central role are certainly Facebook, Twitter, Instagram, Tumblr, Pinterest and LinkedIn (Alalwan et al., 2017; Amatulli, Peluso, \& Colella, 2017). These digital platforms also represent an important communication channel for luxury brands that intend to involve their customers (Kim \& Ko, 2012), albeit the brands are always attentive to image and reputation, which are considered the determinants of e-reputation (Castellano \& Khelladi, 2016). However, the marketing literature has paid little attention to what influence social media has on consumer behaviour in the luxury context (Godey et al., 2016; Martín-Consuegra, Díaz, Gómez, \& Molina, 2019; Prentice \& Loureiro, 2018). Interestingly, Okonkwo (2007), who has extensively investigated the relationship between luxury and the Internet, underlined that the luxury sector has been rather slow to embrace the digital revolution and its slow rise is dictated by the concern in the industry that it might lose its aura of exclusivity. Thereafter, Kim and Ko (2012), in their empirical study of luxury fashion brands, affirm the importance of social media marketing activities to obtain a future profit. At the same time, Godey et al (2016), through an analysis of social media marketing efforts associated with luxury brands, broadened the vision of the social media marketing paradigm by identifying five characterising aspects, including entertainment, interaction, tendency, personalisation and word of mouth (WOM).

The present research is aimed at exploring and evaluating the relationship between luxury and social media through a qualitative approach, that is, by analysing what the marketing literature has explored concerning the role of social media in luxury marketing. From a methodological viewpoint, the present study has been inspired by the research method adopted by Tranfield, Denyer and Smart (2003), therefore, it is based on a review of the main theoretical contributions thus far published on social media marketing and luxury. The results offer an overview of insights concerning the role of social media in luxury marketing, with a particular focus on luxury consumption. This paper contributes to the literature on luxury consumption by shedding light on state-of-the-art research concerning the way social media marketing is impacting the purchase of luxury goods and brands. Furthermore, this study also contributes to the literature on social media marketing by underlining how luxury brands manage their branding and communication strategies on social media platforms. Finally, by elaborating 
on the research insights on social media marketing and luxury, this study offers managerial implications for luxury brand managers who need to understand better how to use digital platforms in their business and who need to know more about how luxury consumption is evolving in the digital context.

\section{Social Media Marketing}

Social media represents an online information source used by consumers who want to share information with other consumers on topics of common interest (Blackshaw \& Nazzaro, 2004). Social media allows for a two-way conversation with consumers who collaborate in the development of the identity or image of a brand (Lim, Chung, \& Weaver, 2012) and who represent online platforms that facilitate interactions, joint work or content sharing (Richeter \& Koch, 2007) on the Internet through publishing or blogging activities (Lim et al., 2012). However, the broad concept of social media tends to include other types of tools, such as blogs, microblogs, online assessments, social bookmarking, forums and other social media platforms that often combine some of these tools (Alalwan et al., 2017; Amatulli et al., 2017; Kaplan \& Haenlein, 2010). There are several definitions of social media derived from scientific academic studies; Russo, Watkins, Kelly and Chan (2008), define social media as applications that facilitate a participatory cultural experience and online collaboration within institutions. In social media marketing context referring to goods and services, among the definitions of social media, the most relevant is offered by Kaplan and Haenlein (2010), who define it as 'a group of Internet-based applications that build on the ideological and technological foundations of Web 2.0, which allows the creation and exchange for user-generated content' (p. 61). From this definition, several scholars have offered their interpretation of social media as applications based on Web 2.0 technologies (Kietzmann, Hermkens, McCarthy, \& Silvestre, 2011; Obar \& Wildman, 2015; Zembik, 2014) able to facilitate interactivity, co-creation and user-generated content development and sharing (Kaplan \& Haenlein, 2010) between organisations and individuals (Filo et al., 2015; Kietzmann et al., 2011). Leonardi, Huysman and Steinfield (2013), also affirm that social media represents tools for internal communication and social interaction within the company. More recently, also think of the broader context, social media has been defined as a place where people, organisations and even governments interact at the commercial, social, political and educational levels (Alalwan, 2018). A summary of the main definitions of social media are reported in Table 1. 
Table 1. Main definitions of social media

\begin{tabular}{|c|c|}
\hline Author & Definitions \\
\hline Blackshaw and Nazzaro (2004) & $\begin{array}{l}\text { Social media represent a variety of new online information sources, created and used by } \\
\text { consumers who want to share information with others about topics of common interest }\end{array}$ \\
\hline Richeter and Koch (2007) & $\begin{array}{l}\text { Social media is an online media and content application or platform of all kinds that facilitates } \\
\text { interactions, collaborations and sharing among users. }\end{array}$ \\
\hline Russo, Watkins, Kelly and Chan (2008) & $\begin{array}{l}\text { Social media applications have the function of facilitating a participatory cultural experience } \\
\text { and online collaboration within institutions. }\end{array}$ \\
\hline Kaplan and Haenlein (2010) & $\begin{array}{l}\text { Social media is "a group of Internet-based applications that build on the ideological and } \\
\text { technological foundations of Web 2.0, which allows the creation and exchange for } \\
\text { user-generated content". (p. 61) }\end{array}$ \\
\hline Xiang and Gretzel (2010) & $\begin{array}{l}\text { Social media is intended as the first tools on the Internet that carry consumer-generated } \\
\text { content }\end{array}$ \\
\hline $\begin{array}{l}\text { Kietzmann, Hermkens, McCarthy and } \\
\text { Silvestre (2011) }\end{array}$ & $\begin{array}{l}\text { Social media are platforms that use mobile technologies and web-based highly interactive in } \\
\text { which individuals and communities share, co-create, discuss and modify user-generated } \\
\text { content. }\end{array}$ \\
\hline Lim, Chung and Weaver (2012) & $\begin{array}{l}\text { Social media allow a two-way conversation with consumers who collaborate in the } \\
\text { development of the identity or image of the target brand and the applications refer to typical } \\
\text { internet activities such as posting, tagging, digging, or blogging. }\end{array}$ \\
\hline De Vries, Gensler and Leeflang (2012) & $\begin{array}{l}\text { Social media are means of communication that foster customer relationships and can be used } \\
\text { to manage customer relationships, marketing communications and branding. }\end{array}$ \\
\hline Leonardi, Huysman and Steinfield (2013) & Social media are tools for internal communication and social interaction within the enterprise. \\
\hline $\begin{array}{l}\text { Rapp, Beitelspacher, Grewal and Hughes } \\
\text { (2013) }\end{array}$ & $\begin{array}{l}\text { Social media are interactive platforms where companies and customers can share information } \\
\text { and content about the brand and products within the network }\end{array}$ \\
\hline Zembik (2014) & $\begin{array}{l}\text { "Social media is the Internet and mobile applications whose overriding idea is to enable social } \\
\text { interaction". (p. 134) }\end{array}$ \\
\hline Obar and Wildman (2015) & $\begin{array}{l}\text { Social media are applications Internet } 2.0 \text {-based where user-generated content is its lifeblood. } \\
\text { These also facilitate the development of online social networks by linking profiles of single } \\
\text { peoples or groups of peoples. }\end{array}$ \\
\hline Filo, Lock and Karg (2015) & $\begin{array}{l}\text { Social media are new multimedia technologies that facilitate interactivity, co-creation, } \\
\text { development and sharing of user-generated content among organizations and individuals. }\end{array}$ \\
\hline $\begin{array}{l}\text { Godey, Manthiou, Pederzoli, Rokka, } \\
\text { Aiello, Donvito and Singh (2016) }\end{array}$ & $\begin{array}{l}\text { Social media offer great opportunities to reach and create more personal relationships with } \\
\text { consumers in their social communities and have changed the way brand content is created, } \\
\text { distributed and consumed. }\end{array}$ \\
\hline Kumar, Choi and Greene (2017) & $\begin{array}{l}\text { Social media has changed the way companies attract and retain customers who in turn can } \\
\text { interact with each other and with the company }\end{array}$ \\
\hline Alalwan (2018) & $\begin{array}{l}\text { Social media are platforms increasingly used for marketing and advertising activities and } \\
\text { represent the place where people, organizations and even governments interact at a } \\
\text { commercial, social, political and educational level. }\end{array}$ \\
\hline $\begin{array}{l}\text { Kapoor, Tamilmani, Rana, Patil, Dwivedi } \\
\text { and Nerur (2018) }\end{array}$ & $\begin{array}{l}\text { "Social media allows relationship forming between users from distinct backgrounds, resulting } \\
\text { in a tenacious social structure" (p. 531) }\end{array}$ \\
\hline $\begin{array}{l}\text { Martín-Consuegra, Díaz, Gómez and } \\
\text { Molina (2019) }\end{array}$ & $\begin{array}{l}\text { Social media are networks used by brands as two-way communication platforms to the target } \\
\text { audience for the exchange and sharing of instant information and for interactions, creating } \\
\text { reliable experiences for consumers and brand loyalty }\end{array}$ \\
\hline
\end{tabular}

Source: Elaboration of the authors.

Always in the context of social media, some studies underline that the use of social media by companies tends to increase the exhortation of the brand, as well as the WOM among consumers, having a positive effect on their purchase intentions and increasing brand loyalty (Dholakia \& Durham, 2010; Kim \& Ko, 2012; Labrecque, 2014; Martín-Consuegra et al., 2019). Furthermore, these interactive and user-controlled platforms offer users the opportunity to share their buying experiences (Arrigo, 2018). However, this positive effect on their purchase intentions tends to be reduced because the enormous amount of information generated on the platforms makes it difficult for users to find credible information (Kapoor et al., 2018).

The development of social media platforms and the production of the aforementioned effects have aroused in both marketing managers and scholars a strong interest in exploring and studying this phenomenon (Alalwan et al., 2017; Arrigo, 2018; Dwivedi, Kapoor, \& Chen, 2015; Felix, Rauschnabel, \& Hinsch, 2017; Godey et al., 2016; Kim \& Ko, 2012; Wang \& Kim, 2017).

In this context, the theoretical location of social media marketing can be considered. Nowadays, indeed, the 
social media marketing function is implemented in all sectors through social media platforms and channels with the aim of creating, communicating, distributing and exchanging offers of a certain value (Tuten \& Solomon, 2017). In some ways, social media has created a new generation of customers much more powerful and sophisticated (Barreda, Bilgihan, Nusair, \& Okumus, 2016; Palla, Tsiotsou, \& Zotos, 2013) and difficult to influence, persuade and conserve because they cannot physically evaluate the quality of products (Alalwan, 2018; Constantinides, 2014). Moreover, according to Godey et al. (2016), in defining the best social media marketing strategy, it is necessary to consider five important aspects: entertainment, interaction, trend, personalisation and WOM (e.g., Kim \& Ko, 2012), as they positively influence the achievement of a brand image and increase brand loyalty

Interestingly, through the definition of their holistic framework of strategic elements of social media marketing, Felix et al. (2017) identify four dimensions underlying the social media marketing strategies: finality, culture, structure and governance. Thus, they offer a new definition of social media marketing: Social media marketing is an interdisciplinary and cross-functional concept that uses social media to achieve organizational goals by creating value for stakeholders. On a strategic level, social media marketing covers an organization's decisions about social media marketing scope, culture, structure, and governance (p. 123).

Although this definition can be considered complete, Alalwan et al. (2017) underline the importance of research focusing on how the phenomenon of marketing can behave differently from one platform to another, especially in relation to the different geographical contexts, whether they are developed, emerging or in the process of being developed.

As already highlighted by Kapoor et al. (2018), social media platforms are generators of infinite information, and consumer reviews are a key element of the quality, credibility and authenticity of information. In this context, according to Jacobson, Gruzd and Hernández-García (2019), the data derived from the activities of social media marketing are relevant for two reasons: a) marketers mainly engage in opinion mining to create targeted advertising and relate to customers and $b$ ) they strengthen the development of solid relationships with customers through user-generated content (Filo et al., 2015; Kaplan \& Haenlein, 2010) and involving them in two-way online social interactions (Wang \& Kim, 2017). In this way, the development of targeted advertising will lead to the creation of a strong competitive advantage on the market (Gundecha \& Liu, 2012). In addition, the solidity of the relationships obtained through online social interaction will allow the implementation of a system for managing relations with social customers (Wang \& Kim, 2017) through systems that collect data on social media and gather personal information that is more detailed.

Therefore, social media marketing has become a research field rich in different facets, especially because it is now used across sectors (Alalwan et al., 2017; Jacobson et al., 2019). In particular, this study will focus on the luxury sector and on how luxury brands have been approached by this new form of communication.

\section{Luxury, Luxury Brands and Luxury Consumption}

In the last decades, the luxury market has grown and the consumption of luxury goods reached $920 \mathrm{~B} €$ in 2018 , increasing from $915 \mathrm{~B} €$ in 2017, with 4-5\% expected annual growth until 2025 (The Boston Consulting Group, 2019). From these data, it is clear that despite the economic crisis that occurred in recent decades, the luxury sector continues to grow. Interestingly, the level of growth of experiential luxury (590 B€, $+5 \%$ on 2017), which is more than that of personal luxury ( $330 \mathrm{~B} €,+3 \%$ compared to 2017), is driven by both millennials and the Chinese (The Boston Consulting Group, 2019). Importantly, consumers of luxury goods nowadays represent a broader segment compared to the past; that is, consumers are characterised by moderate purchasing power and defined as 'excursionist' (Dubois \& Laurent, 1996; Dubois, Laurent, \& Czellar, 2001; Dubois, Czellar, \& Laurent, 2005; Kapferer \& Valette-Florence, 2018). Therefore, since the nineties, the interest of scholars in luxury consumption has increased, with the aim to explore the concept of luxury (Dubois \& Paternault, 1995; Liebenstein, 1950; Veblen 1899), investigate the dimensions of luxury brands (Ko, Costello, \& Taylor, 2019; Phau \& Prendergast, 2000; Vigneron \& Johnson, 1999; 2004) and identify the drivers of luxury consumption (Amatulli \& Guido, 2011; Müller-Stewens \& Berghaus, 2014; Vigneron \& Johnson, 1999).

Because of the relevance of luxury from an economic viewpoint, several scholars have started studying luxury and luxury consumption with the aim to define luxury. However, although various disciplines have been involved in the definition of luxury, a clear and univocal definition of luxury is still missing (Belk, 1999; Mundel, Huddleston, \& Vodermeier, 2017). Belk (1999) focuses on the differences the concept of luxury assumes among Western countries and emerging economies in the luxury sector, such as Russia and China, stating that the closer an item is considered to being a necessity, the less it will be considered a prestigious object. To illustrate, Heine and Phan (2011) affirm that the non-uniqueness of the concept of luxury is derived from three different 
motivations. First, scholars do not discriminate the various concepts of luxury so far defined. Second, scholars tend to formulate luxury concepts related to specific products, not considering that nowadays, luxury products, as affirmed by Lipovetsky and Roux (2003), differ highly from traditional products. Finally, scholars tend to include only a few essential features in their definitions of luxury, ignoring others that are likely relevant, such as culture, because certain aspects of the luxury conception can be found at a rather different point than in another culture (Belk, 1999). Luxury certainly represents a broad and profitable sector, defined as a significant growth engine in many countries (Amatulli, De Angelis, Pichierri, \& Guido, 2018).

Relevant studies have defined luxury as a display of one's wealth to society (Veblen, 1899) by considering the dream as its main dimension (Dubois \& Paternault, 1995). According to Vigneron and Johnson (2004), luxury is the satisfaction of both the functional and psychological needs linked to the perceived characteristics of the product, such as quality, aesthetics and elitism. Indeed, luxury could represent a key factor differentiating a brand in a product category by making it preferable to others by the consumer (Wiedmann, Hennigs, \& Siebels, 2009). Furthermore, the luxury market could be considered made up of three levels: 'inaccessible luxury', 'intermediate luxury' and 'affordable luxury' (Alleres, 1991; De Barnier, Falcy, \& Valette-Florence, 2012). According to Alleres (1991), affordable luxury represents for consumers the belonging to a social class, and consumption derives from an object of desire. Intermediate luxury is the means for the middle class to offer value, such as excellence or aesthetics, and the dream of luxury at an affordable price. Finally, inaccessible luxury is destined for a distinct social class that can afford traditional, rare and unique items.

According to Heine and Phan (2011), at the basis of the definition of luxury, three perspectives are considered, that is, the psychological-sociological, the microeconomic and the managerial. Indeed, marketing managers and scholars have explained the concept of luxury and the meaning of luxury goods, and the most important definitions are offered by the research of Veblen (1899) and Kapferer (1997). These studies intertwine various meanings that are considered equivalent, such as the high cost of goods, elevation at the social level, the handicraft manufacture, the ostentation and value and whether it is symbolic or functional (Kapferer, 1997; Kapferer \& Bastien, 2015; Veblen, 1899). In this sense, Prokopis and Vassou (2014) even suggest that the concept of luxury can be defined as subjective and personal. Therefore, over the centuries, the concept of luxury has undergone substantial changes, becoming a real expression of itself and eliminating the sense of depravity or elitism with which it was first associated (Chandon, Laurent, Pierre, \& Valette-Florence, 2016). The main definitions of luxury brands are summarised in Table 2. 
Table 2. Main definitions of luxury

\begin{tabular}{|c|c|}
\hline Author & Definitions \\
\hline Veblen (1899) & Luxury as ostentation of one's own wealth towards society. \\
\hline Liebenstein (1950) & $\begin{array}{l}\text { Takes up the concepts of ostentation proposed by Veblen proposing three different } \\
\text { ostentation effects: Veblen, Snob and Bandwagon that returning to the sphere of luxury } \\
\text { consumption hetero-referential }\end{array}$ \\
\hline Dubois and Paternault (1995) & Luxury must contain the dream as its main dimension. \\
\hline Nueno and Quelch (1998) & $\begin{array}{l}\text { Luxury represents both the intrinsic quality of a product and the intangible qualities } \\
\text { validated by the luxury brand }\end{array}$ \\
\hline Nia and Lynne Zaichkowsky (2000) & $\begin{array}{l}\text { Luxury is a state of prestige for those who hold a good that falls within its category where } \\
\text { functional utility is not considered }\end{array}$ \\
\hline Vigneron and Johnson (2004) & $\begin{array}{l}\text { Luxury is the satisfaction of both functional and psychological needs related to the } \\
\text { characteristics perceived by the product, such as quality, aesthetics and elitism. }\end{array}$ \\
\hline Mortelmans (2005) & $\begin{array}{l}\text { Luxury is a mix of features, is a question of seeing and being seen having an objective or } \\
\text { symbolic extra value }\end{array}$ \\
\hline Dubois, Czellar and Laurent (2005) & $\begin{array}{l}\text { Luxury is not synonymous with a narrow and selective idea of "good taste" reserved only for } \\
\text { "refined" people, it is not a tool of differentiation from others and is not necessarily very } \\
\text { expensive }\end{array}$ \\
\hline Yeoman and McMahon-Beattie (2006) & $\begin{array}{l}\text { Luxury is no longer a phenomenon confined to the real bourgeoisie, but a phenomenon of } \\
\text { mass marketing of everyday life such with increased affluence which is no longer the } \\
\text { preserve of the elite. }\end{array}$ \\
\hline Wiedmann, Hennigs and Siebels (2007) & Luxury is a subjective and multidimensional construct \\
\hline Wiedmann, Hennigs and Siebels (2009) & $\begin{array}{l}\text { Luxury is a key factor in differentiating a brand in a product category as well as a central } \\
\text { driver of consumer preference and usage }\end{array}$ \\
\hline Heine and Phan (2011) & Luxury is anything that is desirable and more than necessary and ordinary \\
\hline Hansen and Wänke (2011) & $\begin{array}{l}\text { Luxury is the exception to the rule, a special treatment that is out of the ordinary where most } \\
\text { consumers cannot afford to indulge in luxury every day. }\end{array}$ \\
\hline Yeoman (2011) & $\begin{array}{l}\text { Luxury is now more accessible and democratized to the masses. This tends to damage the } \\
\text { exclusivity that luxury products have always had. }\end{array}$ \\
\hline Choo, Moon, Kim, and Yoon (2012) & $\begin{array}{l}\text { Luxury is a mix of products, services or brands of high price, excellent quality, aesthetic } \\
\text { beauty, pleasure, exclusivity or rarity }\end{array}$ \\
\hline $\begin{array}{l}\text { De Barnier, Falcy, and Valette-Florence } \\
\text { (2012) }\end{array}$ & $\begin{array}{l}\text { Luxury includes three domains, such as inaccessible luxury, intermediate luxury and } \\
\text { accessible luxury }\end{array}$ \\
\hline Kapferer and Michaut (2015) & $\begin{array}{l}\text { Luxury represents a relatively small sector of the economy attract increased attention and } \\
\text { have become highly visible }\end{array}$ \\
\hline $\begin{array}{l}\text { Mundel, Huddleston and Vodermeier } \\
\text { (2017) }\end{array}$ & $\begin{array}{l}\text { Luxury represents an increasingly affordable consumption, especially if considered } \\
\text { consumers of the new millennium, the millennial. }\end{array}$ \\
\hline $\begin{array}{l}\text { Pantano, Passavanti, Priporas and } \\
\text { Verteramo (2018) }\end{array}$ & $\begin{array}{l}\text { Luxury represents rich people with rich lives, a sort of exclusive and inaccessible lifestyle and } \\
\text { consumption is driven by social attributes such as self-expression and self-presentation, and } \\
\text { the need to exhibit a social position. }\end{array}$ \\
\hline $\begin{array}{l}\text { Amatulli, De Angelis, Pichierri and Guido } \\
\text { (2018) }\end{array}$ & $\begin{array}{l}\text { "Luxury is a large and lucrative sector serving as one of the most relevant engines of growth in } \\
\text { many countries" (p. } 72 \text { ) }\end{array}$ \\
\hline Stathopoulou and Balabanis (2019) & $\begin{array}{l}\text { Luxury represents abstractness and is often related to notions of quality, social status, } \\
\text { exclusivity, premium price, heritage and authenticity. This, however, is strongly influenced by } \\
\text { the human element, since the term stands between products, elements or real, objective } \\
\text { experiences and subjective images produced in the minds of consumers. }\end{array}$ \\
\hline
\end{tabular}

Source: Elaboration of the authors.

When dealing with luxury, an important topic is that of luxury brands. Semiotic scholars have identified luxury codes, despite the relativity of the concept of luxury (Maman Larraufie \& Kourdoughli, 2014). Ko et al. (2019), through a revision of the concept of the luxury brand, intended to define a theoretical framework that responds to three key criteria. These include the mere conceptualisation of the luxury brand and the applicability of this broad form of conceptualisation, the generalisation of products and services. It is furthermore included an operativity of the theory to measure the principles of the concept of a luxury brand. The result of this examination is represented by five measures: authenticity, quality, resonance, prestige and premium price, which offer a unique definition of a luxury brand, although studies and measurement diagrams argue that even visibility could be considered a measure attributable to the consumption of luxury brands (Dubois et al., 2001; Ko et al., 2019; Vigneron \& Johnson, 2004). According to Keller (2009), a luxury brand consists of 10 characteristics: a premium image; the creation of intangible brand associations; tangible elements, such as logos, symbols and 
packaging design; secondary associations with links to personalities or endorsers; a controlled distribution; premium prices; careful management; a broad definition; legal protection of trademark; and quality. From an analysis of the literature, it has emerged that quality is a shared characteristic in most studies (Heine, 2010; Hudders, Pandelaere, \& Vyncke, 2013; Keller, 2009; Ko et al., 2019; Okonkwo, 2007; Vigneron \& Johnson, 2004). The main definitions of luxury brands are summarised in Table 3.

Table 3. Main definitions of luxury brands

\begin{tabular}{|c|c|}
\hline Author & Definitions \\
\hline Roux (1991) & $\begin{array}{l}\text { Luxury brand is characterized by an added symbolic, imaginary or social value that } \\
\text { differentiates it from other brands }\end{array}$ \\
\hline Alleres (1991) & Luxury brands tend to form a unique and exclusive family of brands, different from others. \\
\hline Kapferer (1997) & $\begin{array}{l}\text { Luxury brands are distributed along a space-time ray to express the degree of luxury that } \\
\text { each brand represents. }\end{array}$ \\
\hline Phau and Prendergast (2000) & $\begin{array}{l}\text { Luxury brands are represented by four fundamental characteristics, such as exclusivity, } \\
\text { exceptional brand identity, high awareness of the brand contextual to the perception of } \\
\text { quality and the maintenance of contained sales levels making sure customer brand loyalty }\end{array}$ \\
\hline Vickers and Renand (2003) & $\begin{array}{l}\text { Luxury brands contain primary functional dimensions and solve the typical needs of } \\
\text { extrinsic consumption relative to the physical product. }\end{array}$ \\
\hline Vigneron and Johnson (2004) & $\begin{array}{l}\text { Luxury brand is based on three levels: up-market, premium and luxury and the associated } \\
\text { level of luxury is measured by conspicuousness, uniqueness, quality, hedonism and extended } \\
\text { self. }\end{array}$ \\
\hline Okonkwo (2007) & $\begin{array}{l}\text { Luxury brands are represented by different factors, such as high visibility, distinct identity, } \\
\text { reputation, emotional appeal, innovation, creativity and uniqueness which in turn guarantee } \\
\text { quality and premium price. }\end{array}$ \\
\hline Hagtveded and Patrick (2009) & $\begin{array}{l}\text { Luxury brands offer the consumer a premium product, arousing pleasure as a central } \\
\text { advantage and connecting with consumers on an emotional level. }\end{array}$ \\
\hline Keller (2009) & $\begin{array}{l}\text { Luxury brand consists of ten characteristics, such as a premium image, the creation of } \\
\text { intangible brand associations, quality, tangible elements such as logos, symbols and } \\
\text { packaging design, secondary associations with links to personalities or endorsers, a } \\
\text { controlled distribution, premium prices, careful management, broad definition and legal } \\
\text { protection of trademarks. }\end{array}$ \\
\hline Heine (2010) & $\begin{array}{l}\text { Luxury brands are regarded as images in the minds of consumers that comprise of } \\
\text { associations with a high price, quality, aesthetic, rarity and specialty }\end{array}$ \\
\hline Hudders (2012) & $\begin{array}{l}\text { Luxury brand has precise characteristics, such as a premium quality and an aesthetically } \\
\text { attractive design, and can be defined as exclusive, which implies expensiveness and/or rarity. }\end{array}$ \\
\hline Hudders, Pandelaere and Vyncke (2013) & $\begin{array}{l}\text { Luxury brands are represented by a mix of features such as exclusivity, uniqueness, scarcity, } \\
\text { premium price, excellent quality and aesthetics. }\end{array}$ \\
\hline Sung, Choi, Ahn and Song (2015) & $\begin{array}{l}\text { Luxury brand is identified in six dimensions: a) excitement, b) sincerity, c) sophistication, d) } \\
\text { professionalism, e) attractiveness and f) materialism. }\end{array}$ \\
\hline Roux, Tafani and Vigneron (2017) & $\begin{array}{l}\text { Luxury brands have the function of transmitting two personal values that derive from private } \\
\text { and self-directed benefits such as hedonism and perfectionism }\end{array}$ \\
\hline Kapferer and Valette-Florence (2018) & $\begin{array}{l}\text { The importance of uniqueness for luxury brands nowadays varies across international } \\
\text { cultures. }\end{array}$ \\
\hline Ko, Costello and Taylor (2019) & $\begin{array}{l}\text { They attribute to the luxury brands five implicit measures among them, such as quality, } \\
\text { authenticity, resonance, prestige and premium price. }\end{array}$ \\
\hline
\end{tabular}

Source: Elaboration of the authors.

Another fundamental aspect to be analysed in relation to luxury is the motivation to consume. In this framework, motivational patterns that can be associated with luxury consumption are considered and defined as central drivers, social factors and individual factors (Müller-Stewens \& Berghaus, 2014; Vigneron \& Johnson, 1999). Several studies are expressed on the social factors and individual factors (De Barnier et al., 2012; Veblen, 1899; Vigneron \& Johnson, 1999, 2004). Leibenstein (1950) identified three different effects that justify luxury consumption, Veblen, Snob and Bandwagon, in which respectively ostentation, differentiation and conformism the basis to three effects. However, individual factors include hedonism and perfectionism, and they focus on experiential consumption (Müller-Stewens \& Berghaus, 2014; Vigneron \& Johnson, 1999, 2004).

Stability the magnitude these two factors, it is intended to focus attention on the double dimension that several studies associate to the concept of luxury consumption (Amatulli \& Guido, 2011, 2012; Truong, 2010). Let us take the motivational, personal or interpersonal aspects, whether intrinsic or extrinsic (Vigneron \& Johnson, 
1999, 2004), or consider the double dimension of luxury consumption attributable to the dichotomy between interiorised luxury and exteriorised luxury (Amatulli \& Guido, 2012). In this sense, nowadays, there is interest among researchers studying phenomena related to the growth of the luxury brand market (Ko et al., 2019). In addition, the academic literature has associated clear forms of consumer behaviour related to luxury goods, explaining the distinction between ostensive consumption and hedonistic consumption, respectively defined as internalised consumption and exteriorised consumption (Amatulli \& Guido, 2011; Guido, De Matteis, Pino, \& Amatulli, 2017).

According to Guido et al. (2017), however, the main reasons associated with luxury consumption are represented by external motivations and internal motivations, which define a dichotomous approach to the consumption of luxury, internalised luxury and exteriorised luxury. In internalised luxury, consumption is of the experiential type that is driven by emotions and sensations, as opposed to externalised luxury, in which luxury consumption is driven by the desire for approval from society (De Barnier et al., 2006; Vigneron \& Johnson, 2004). Amatulli and Guido (2012) tried to outline a theoretical framework that explained precisely the dichotomy between internalised luxury and externalised luxury, starting from the analysis of the main constructs until obtaining a real conceptual model. Therefore, it follows that, at the base of the concept of luxury consumption that we want to analyse, a substantial divergence emerges. Internalised consumption is attributable to the individual lifestyle, hedonistic consumption and culture (Amatulli \& Guido, 2011; 2012). Externalised consumption, on the other hand, is mainly based on the principles relating to ostentation - as an externalisation of its high purchasing power-and materialism (Belk, 1985). These are understood as possessiveness, envy and greed towards other categories of subjects, determining a level of superfluity in the purchased product (Amatulli \& Guido, 2011; Belk, 1985; Dubois et al., 2001). Indeed, Amatulli, Guido and Nataraajanl (2015), underline that those who attach greater importance to visibility adopt a more externalised approach to luxury than do those who primarily have an internalised luxury approach.

\section{Social Media Marketing and Luxury Consumption}

Nowadays, the main social media sites offer companies the possibility to create web pages for their marketing communication (Jahn, Kunz, \& Meyer, 2012). In this sense, social media marketing has consolidated its importance in the luxury sector (Okonkwo, 2009). It is interesting to note that the main levers $(92 \%$ millennials vs $81 \%$ overall true luxury) of influence over the purchase (i.e., China) of luxury brands remain social media platforms and influencers (The Boston Consulting Group, 2019).

Concerning motivations, Jahn et al. (2012) identify three areas in which consumers use social media in a luxury context. To illustrate: a) the relationship, or staying connected and interacting with other consumers and with companies (Essamri et al., 2019; Kim \& Ko, 2012) online; b) the acquisition, distribution and co-creation (Phan et al., 2011) of contents, whether functional or hedonistic (Hagtveded \& Patrick, 2009; Vigneron \& Johnson, 2004); and c) self-presentation (Jahn et al, 2012; Jin, 2012), which is linked to the social context and personal identity. Therefore, among the main motivations pushing the consumers of luxury goods towards the use of social media is self-presentation, which is based on its visibility dimension of luxury (Jahn et al., 2012).

In this context, studies have specified which efforts social media marketing activities have implemented in the luxury context (Kim \& Ko, 2012; Godey et al., 2016; Phan, Thomas, \& Heine, 2011).

According Phan et al. (2011), to develop an efficient marketing strategy and to improve the customer experience and perceptions of their brands, luxury brands must have a clear understanding of the concept of social media marketing and the potential offered by them to drive sales (Chu, Kama, \& Kim, 2013). A significant aspect that emerged from these studies is the level of interactivity that luxury brands have acquired in recent years, particularly concerning the interactivity that consumers have in the various decision-making processes in the purchase of luxury goods.

Kim and Lee (2019) affirm that in the context of luxury consumption, interaction involves the reproduction of users who share, spread and defend their ideas, values and experiences and who support brands and products (Kim et al., 2012). The disruptive digitalisation process of the communication systems of companies an important role is played in which it needs an increase their skills in analysing the relationship between luxury and the customer on the web (Amatulli et al., 2017). According to Okonkwo (2009), the consumer through social media often has the perception of having full control over his or her choices, generating a particular form of apprehension on the part of the luxury brand (Godey et al., 2016). Therefore, modern luxury consumers are gradually turning their attention to social media platforms (Martín-Consuegra et al., 2019), and according to Yu, Cho and Johnson (2017), the activities carried out on social media platforms tend to increase consumers experience, involvement with the brand, interactivity and brand loyalty. 


\section{Qualitative Study and Results}

The present review has a dual aim: 1) identifying, evaluating and discovering to what extent previous research relating to social media marketing and the luxury brand has adapted, and 2) proposing further insights from the literature and possible future research directions.

The need to integrate these two perspectives within the luxury marketing literature stems from the fact that still little research has been conducted on these issues. Furthermore, an in-depth study on the methodological approach and on the systematic process that was undertaken in the present literature review is fundamental.

\subsection{Methodology}

This study is aimed at shedding light on the relationship between luxury and social media by analysing the current literature. Indeed, by analysing the existing literature on luxury consumption and social media, this study offers an updated overview of the academic investigation of the role of the Internet in luxury and in luxury consumption. In this review, a qualitative approach has been adopted, as it has allowed us to understand better a complex phenomenon, that is, the role of social media in luxury (Corbetta, 2009). Specifically, among the various qualitative research methods, we decided to adopt an approach close to the systematic review. Our review was implemented by partially following the systematic review process proposed by Tranfield et al. (2003) (see also Salo, 2017), which is considered a valid and practical means for improving existing knowledge in a specific field of research. Indeed, not all the steps envisaged by the systematic review process proposed by Tranfield et al. (2003) have been considered in this study. Instead, we deliberated the phases we considered more relevant to the present research, namely the identification for the need for a review, the preparation of a proposal for a review, the development of a review protocol, the selection of studies, the data extraction, the data synthesis and, finally, the report and dissemination.

The first phase was aimed at finding potential research gaps in the literature to identify a specific research issue. The second phase included an analysis of the existing literature using a qualitative approach to social media marketing, luxury and luxury consumption. The third phase was aimed at the extrapolation of data from the selected documents and the fourth phase concerned identifying the gap in the scientific research and describing the results obtained from the systematic review process.

Having defined the problem and the operational strategy, we moved on to the second phase of execution, in which we identified and selected studies using search engines of international journals (ScienceDirect, Elsevier, Google Scholar, ResearchGate), the most suitable method for this type of revision (Alalwan et al., 2017). Moreover, we selected a number of keywords in the search, such as Social media, Luxury marketing, Luxury brands, Luxury externalised and Internalised luxury. Different journals and relevant research have been identified in terms of their content and affinity with previously planned research topics.

The research with the greatest impact was selected through an article inclusion and exclusion operation, and we extrapolated the data from the selected papers, defining inside synoptic tables the author, year, name of the paper, methodology used, variables considered in the research, results and type of study (see Appendix A). The abstracts and highlights were useful for analysing the papers, which was done according to specific criteria, such as the scientific relevance of the contribution, the validity of the methodology and the quality of the results analysis (Arrigo, 2018). The analysis showed interesting data on the research methodology most used to assess the role of social media in luxury; that is, we found an empirical prevalence of quantitative approaches, noting a limited amount of literature reviews and qualitative methodological approaches.

The data analysis was carried out through a process of data extrapolation, following an accurate and thorough reading of the studies. In this phase, we used a structured research framework based on an analysis of specific elements, such as the research theme (akin to the research question), the methodology of data collection and analysis and the type of research (qualitative, quantitative or review). The reading of the highlights and the identification of insights were significant, as it was possible to outline in general the state-of-the-art research carried out up to now, emphasising from the beginning what research themes were identified so far and detailed in this paper subject to review. Concerning insights, however, they were obtained through a careful reading of the conclusions, discussions and future research projections proposed by scholars. 


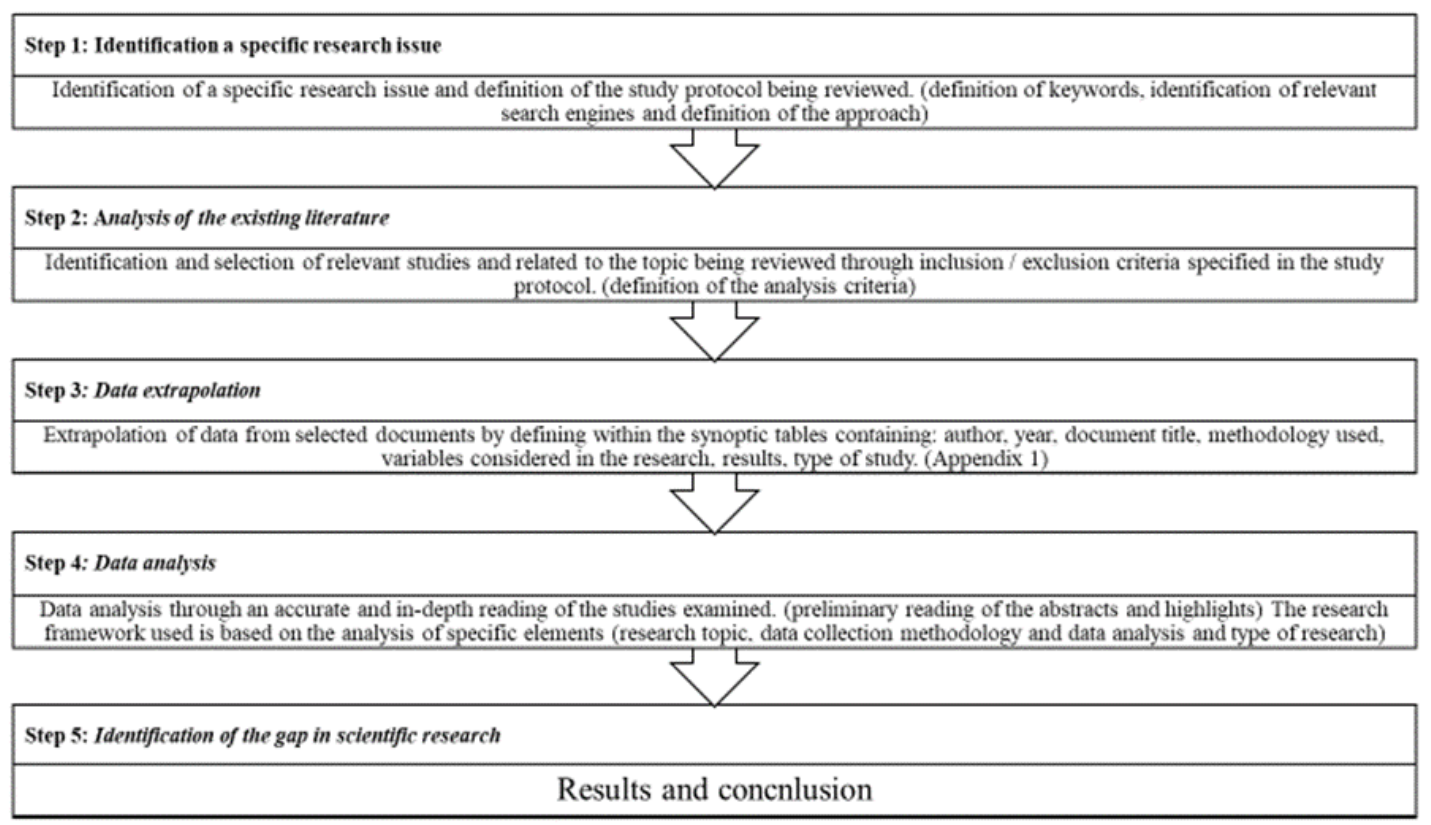

Figure 1. Flow-chart research methodology

Source: Elaboration of the authors.

\subsection{Insights from the Literature}

The first important data that emerge from the analysis of the existing literature show that studies on the activities of social media marketing in the context of luxury brands are scarce; in particular, the existing studies adopt a qualitative approach. The objective of this review is to analyse and evaluate the research and results obtained thus far by identifying highly relevant contributions. In this phase, and we aim to identify the fundamental variables useful for carrying out future studies that are more specific and that define the state of the art in luxury and social media. The topics examined in this review are social media marketing, luxury and luxury consumption. The goal is to offer greater clarity to the implementation of social media marketing activities in the context of luxury brands. Specifically, in this review, how consumer behaviour and purchase intentions are related to luxury goods in a social media context, the level of awareness and loyalty to luxury brands on social media platforms and best practise advertising activities on social media will be analysed.

\subsubsection{Customer Behaviour and Social Media in Luxury Marketing}

The study of consumer behaviour has always been the subject of marketing studies, as it is necessary for companies to understand how and why consumers act in their purchasing choices (Stankevich, 2017). The marketing literature has paid little attention to what influence social media has on consumer behaviour in the context of luxury (Godey et al., 2016; Martín-Consuegra et al., 2019; Prentice \& Loureiro, 2018). According to Ko et al. (2019), the reasons for the purchase of luxury brands differ from the reasons for the purchase of other brands, and they state that the uniqueness of some factors contributes substantially to the consumption of luxury brands. In this context, recent studies (Godey et al., 2012; Kastakanis \& Voyer, 2014; Ko et al., 2019) have identified culture and country of origin as playing key roles in consumer behaviour and in the decision-making process of purchasing luxury goods.

In a social media marketing context, instead, Alalwan et al. (2017) highlighted the existence of a good number of academic articles focusing on the impact of social media on consumers' buying behaviours and how they are a rich source of information for the customer throughout the decision-making process (Zhu, Wang, Wang, \& Wan, 2016). In this sense, Kim and Lee (2019) state that the influence on and integration of luxury brand communities into social media have a positive effect on attitude, brand loyalty and purchase intentions. Moreover, social media platforms have made the study of the customer behaviour by marketing decision makers for consumer purchasing even more complicated, as the only control over traditional channels is no longer sufficient.

Insight 1: Social media represents a new important source of information for consumers, and online brand communities have positive effects on luxury brands. However, understanding consumer behaviour 
online is more complicated than offline, especially in relation to the high quantity of information stemming from the web that pushes companies to adopt new systems of surveying the data to analyse consumer behaviour.

\subsubsection{Brand Awareness/Brand Loyalty and Social Media in Luxury Marketing}

The brand represents one of the main sources of a competitive advantage (Naatu, 2016). The pursuit of a competitive advantage and the consolidation of brand heritage through different marketing strategies have already been subjects of academic debate (Christodoulides \& De Chernatony, 2010; Godey et al., 2016). In this sense, Christodoulides and De Chernatony (2010) have associated the constructs of brand equity with the figure of the consumer who tends to buy luxury brands for two reasons (Godey et al., 2016): pleasure and as a symbol of success. In addition, their future depends on the balance between these two motivations. As for brand awareness, this can be achieved through an excellent strategy that creates a brand associated with a product or service with specific qualities or characteristics, making it special and unique (Naatu, 2016).

In addition to why luxury goods are consumed, there are secondary factors to consider, such as luxury brand management, luxury brand equity, luxury brand loyalty and premium price (Kim \& Ko, 2012; Ko et al., 2019), namely, strategies that can be associated with social media marketing. Therefore, the implementation of social media marketing strategies in luxury brand strategies has influenced the studies of academic researchers (Godey et al., 2016; Kim \& Ko, 2012), where it was found that the use of social media platforms tends to create a broader link between end consumers and luxury brands. Still, in the context of social media, studies point out that the use of social media marketing strategies by companies tends to increase a brand's exhortation by generating an increase in brand loyalty (Martín-Consuegra et al., 2019).

Essentially, thanks to the use of innovative media, such as social media platforms, marketing managers can broaden their spatial horizons in defining the best branding strategy (Nguyen, Yu, Melewar, \& Chen, 2015). This exploit in particular the variable of interaction with the consumer and consequently implements a mechanism to innovate the brand itself (Alalwan et al., 2017; Godey et al., 2016; Kim \& Lee, 2019; Nguyen et al., 2015). In addition, it preserves the brand's reputation and pays particular attention to the brand image as a determinant of e-reputation (Castellano \& Khelladi, 2016).

Insight 2: Social media represents a great channel for luxury companies that want to communicate their brand online, as they can exploit the interaction with the consumer in online brand communities, paying particular attention to reputation and image, determinants of e-reputation, thus increasing luxury brand equity and luxury brand loyalty.

\subsubsection{Advertising Activities and Social Media in Luxury Marketing}

Advertising activities on social media platforms are growing. In this context, it was interesting to analyse the Facebook report, which shows an exponential increase in advertising revenue of $38 \%$ in 2018 vs 2017, particularly concerning activities on mobile devices (92\%) (Facebook, 2018).

According to Okazaki and Taylor (2013), in the context of social media marketing, three important paradigms explain the development, advantages and disadvantages of advertising on social media: network capability, image transferability and personal extensibility. He and Shao (2018) affirm that another driver linked to the development of advertising activities on social media is the disruptive development of e-commerce through dedicated platforms, such as Amazon, Zalando, etc.

Nowadays, in digital strategies, advertising on social media platforms has become highly relevant and in this context, the pioneers of social media tend to use these platforms to position themselves as 'thought leaders' by assuming the role of market leader (Salo, 2017). According to Alalwan et al. (2017), the use of social media platforms could be a successful driver to communicate a mission with consumers effectively and to communicate promotional activities effectively (Kohli et al., 2015). Furthermore, social media tends to improve significantly the visibility of these activities by redirecting consumer traffic to the advertised commercial page (Dwivedi et al., 2015).

Several studies have analysed (Dwivedi et al., 2015) the relationship between social media marketing and advertising, but in the context of luxury, there is an absence of in-depth information on the subject, both theoretically and empirically. Therefore, given that advertising activities in a social media marketing context represent one of the main means of persuading and influencing consumers in the decision-making process, increasing brand awareness, it is important to study the phenomenon in the context of luxury.

Insight 3: Social media might represent innovative platforms for a luxury brand's advertising activities, as it is economic, efficient and, above all, sustainable. In particular, it might represent a successful driver to 
communicate a mission with consumers better through targeted promotional activities that can persuade and influence their purchase decision-making process and increase brand awareness.

\section{Conclusions and Future Research Directions}

Given the considerable interest in recent years in the phenomenon of social media among researchers (Alalwan et al., 2017; Dwivedi et al., 2015; Filo et al., 2015; Kaplan \& Haenlein, 2010) and in particular the attention given to the connection between this phenomenon and luxury consumption (Kim \& Ko, 2012; Ko et al., 2019, Godey et al., 2016), this study has sought to outline the state of the art in the social media marketing phenomenon in the context of luxury marketing and luxury brands (Arrigo, 2018), enriching the current theoretical framework.

From the perspective of social media, academic research seems to have found a consensus in their definition, referring to the theoretical studies of Kaplan and Haenlein (2010), who define it as 'a group of Internet-based applications that build on the ideological and technological foundations of Web 2.0, which allows the creation and exchange of user-generated content' (p. 61). Concerning luxury consumption, today, it could be considered that consumption is more accessible to a segment of increasingly broader consumers. In this context, digital social media platforms play a decisive role as a key tool in the dissemination of luxury lifestyles, products and services.

Concerning luxury marketing and luxury brands, in the context of social media marketing, first, a fundamental variable that this research wants to highlight is the geography in which luxury consumption is considered. The empirical analyses conducted by academic research (Wang, Yu, \& Wei, 2012; Godey et al., 2016, Alalwan, 2018) have examined only specific cultural and geographical contexts, whether emerging, developing or developed markets, considering only luxury brands already established on the international market. However, important variables, such as image, technological readiness, advertising creativity, community interests and privacy, have not yet been considered. In this sense, a future direction of research in this context could concern empirical studies on international markets, where there are limitations on the use of social media to evaluate the new online advertising mechanisms of a specific luxury brand and, at the same time, to evaluate the behaviour that the consumer assumes. Moreover, the empirical study of these geographic contexts could help academics and marketing managers face the theoretical and managerial implications suggested by Arrigo (2018) concerning the contents, as well as whether they should differ if published in different platforms and which platform is more suitable for sharing specific content.

Second, significant studies have also been conducted at the managerial level. Pantano, Passavanti, Priporas and Verteramo (2018) analysed the extent to which luxury retail could be intelligent by comparing the different luxury sectors; in particular, they analysed the effectiveness of the presence of a digital marketing and innovation department within a company in terms of the knowledge management of sales activities. This study, however, presented several limitations that could be overcome through future empirical research; in fact, the comparison concerned several luxury sectors and the reference sample consisted only of a limited number of large companies in the sector. A more specific research study could be carried out by comparing a sector belonging to the sphere of luxury and one not belonging to the sphere of luxury and by enlarging the sample of companies to be analysed, as well as the sample of geographical and cultural contexts.

Social media can be considered a $360^{\circ}$ marketing tool, as highlighted by Wang and Kim (2017), who state that social media marketing strategies could improve customer relations through social media, thus parrying social Customer Relationships Management as a mediation tool between company and customer. Therefore, a direction of future research on the use of SCRM in the context of luxury marketing could be found in the identification of social media platforms more prepared for a 1:1 interaction between company and customer. Furthermore, the study could also include small and medium-sized enterprises (SMEs) and private individuals, now increasingly protagonists of international fame and growth in the luxury sector.

The luxury sector, therefore, is seeing growth in the use of social media platforms and the implementation of social media marketing activities in its various contexts; for these reasons, fundamental are future studies that will analyse the different methods identified in previous studies, expanding the scope of research and consolidating previously developed constructs. This study, in turn, would favour a theoretical basis to examine the problems related to this emerging area of social media marketing. Furthermore, the present revision could represent a solid theoretical basis for empirical studies on the phenomenon of social media marketing in the field of luxury marketing and luxury brands, aimed at identifying new variables that are reliable but still unexplored and at obtaining results that are more valid. 


\section{References}

Alalwan, A. A. (2018). Investigating the impact of social media advertising features on customer purchase intention. International Journal of Information Management, 42, 65-77. https://doi.org/10.1016/j.ijinfomgt.2018.06.001

Alalwan, A. A., Rana, N. P., Algharabat, R., \& Tarhini, A. (2016a). A systematic review of extant literature in social media in the marketing perspective. The 15th IFIP Conference on e-Business, e-Services and e-Society on Social Media: The Good, the Bad and the Ugly, Swansea, UK. https://doi.org/10.1007/978-3-319-45234-0_8

Alalwan, A. A., Rana, N. P., Dwivedi, Y. K., \& Algharabat, R. (2017). Social media in marketing: a review and analysis of the existing literature. Telematics and Informatics, 34(7), 1177-1190. https://doi.org/10.1016/j.tele.2017.05.008

Alleres, D. (1991). Spécificités et stratégies marketing des différents univers du luxe. Revue Française du Marketing, 132(33), 71-95.

Amatulli, C., De Angelis, M., Pichierri, M., \& Guido, G. (2018). The Importance of Dream in Advertising: Luxury Versus Mass Market. International Journal of Marketing Studies, 10(1), 71-81. https://doi.org/10.5539/ijms.v10n1p71

Amatulli, C., \& Guido, G. (2011). Determinants of purchasing intention for fashion luxury goods in the Italian market: a laddering approach. Journal of Fashion Marketing and Management, 15(1), $123-136$. https://doi.org/10.1108/13612021111112386

Amatulli, C., \& Guido, G. (2012). Externalised vs. internalised consumption of luxury goods: propositions and implications for luxury retail marketing. The International Review of Retail, Distribution and Consumer Research, 22(2), 189-207. https://doi.org/10.1080/09593969.2011.652647

Amatulli, C., Guido, G., \& Nataraajan, R. (2015). Luxury purchasing among older consumers: exploring inferences about cognitive Age, status, and style motivations. Journal of Business Research, 68(9), 1945-1952. https://doi.org/10.1016/j.jbusres.2015.01.004

Amatulli, C., Peluso, A. M., \& Colella, G. (2017). Un'analisi sui commenti in inglese nelle web-community dei luxury brand: spunti per le strategie del marketing del lusso 'Made in Puglia'. Lingue e Linguaggi, 20, 273-291.

Annie, J. S. A. (2012). The potential of social media for luxury brand management. Marketing Intelligence \& Planning, 30(7), 687-699. https://doi.org/10.1108/02634501211273805

Arrigo, E. (2018). Social media marketing in luxury brands: A systematic literature review and implications for management research. Management Research Review, 41(6), 657-679. https://doi.org/10.1108/MRR-04-2017-0134

Barreda, A. A., Bilgihan, A., Nusair, K., \& Okumus, F. (2016). Online branding: development of hotel branding through interactivity theory. Tourism Management, $180-192$. https://doi.org/10.1016/j.tourman.2016.06.007

Belk, R. W (1985). Materialism: Trait aspects of living in a material world. Journal of Consumer Research, 12(3), 265-280. https://doi.org/10.1086/208515

Belk, R. W. (1999). Leaping luxuries and transitional consumers. Marketing issues in transitional economies, 39-54. Springer, Boston, MA. https://doi.org/10.1007/978-1-4615-5009-9_2

Blackshaw, P., \& Nazzaro, M. (2004). Consumer-generated media (CGM) 101: Word-of-mouth in the age of the web-fortified consumer. Retrieved from http://www.nielsen-online.com/downloads/us/buzz/nbzm_wp_CGM101. Pdf

Boyd, D. M., \& Ellison, N. B. (2007). Social network sites: Definition, history, and scholarship. Journal of Computer - Mediated Communication, 13(1), 210-230. https://doi.org/10.1111/j.1083-6101.2007.00393.x

Castellano, S., \& Khelladi, I. (2016). Reputation, image, and social media as determinants of e-reputation: the case of digital natives and luxury brands. International Journal of Technology and Human Interaction, 12(4), 48-64. https://doi.org/10.4018/IJTHI.2016100104

Chandon, J. L., Laurent, G., \& Valette-Florence, P. (2016). Pursuing the concept of luxury: Introduction to the JBR Special Issue on "Luxury Marketing from Tradition to Innovation". Journal of Business Research, 
69(1), 299-303. https://doi.org/10.1016/j.jbusres.2015.08.001

Choo, H. J., Moon, H., Kim, H., \& Yoon, N. (2012). Luxury customer value. Journal of Fashion Marketing and Management: An International Journal, 16(1), 81-101. https://doi.org/10.1108/13612021211203041

Christodoulides, G., \& De Chernatony, L. (2010). Consumer-based brand equity conceptualization and measurement - A literature review. International Journal of Market Research, 52(1), 43-66. https://doi.org/10.2501/S1470785310201053

Chu, S. C., Kamal, S., \& Kim, Y. (2013). Understanding consumers' responses toward social media advertising and purchase intention toward luxury products. Journal of Global Fashion Marketing, 4(3), 158-174. https://doi.org/10.1080/20932685.2013.790709

Constantinides, E. (2014). Foundations of social media marketing. Social and Behavioral Sciences, 148, 40-57. https://doi.org/10.1016/j.sbspro.2014.07.016

Corbetta, P. (2009). Metodologia e tecniche della ricerca sociale. Il Mulino, Bologna.

De Barnier, V., Falcy, S., \& Valette-Florence, P. (2012). Do consumers perceive three levels of luxury? A comparison of accessible, intermediate and inaccessible luxury brands. Journal of Brand Management, 19(7), 623-636. https://doi.org/10.1057/bm.2012.11

De Barnier, V., Rodina, I., \& Valette-Florence, P. (2006). Which luxury perceptions affect most consumer purchase behavior? A cross-cultural exploratory study in France, the United Kingdom and Russia. Congrès Paris-Venise des Tendances Marketing.

De Vries, L., Gensler, S., \& Leeflang, P. S. (2012). Popularity of brand posts on brand fan pages: An investigation of the effects of social media marketing. Journal of Interactive Marketing, 26(2), 83-91. https://doi.org/10.1016/j.intmar.2012.01.003

Dholakia, U. M., \& Durham, E. (2010). One café chain's Facebook experiment. Harvard Business Review, 88, 26-26.

Dubois, B., Czellar, S., \& Laurent, G. (2005). Consumer segments based on attitude towards luxury: empirical evidence from twenty countries. Marketing Letters, 16(2), 115-128. https://doi.org/10.1007/s11002-005-2172-0

Dubois, B., \& Laurent, G. (1996). The functions of luxury: A situational approach to excursionism. ACR North American Advances.

Dubois, B., Laurent, G., \& Czellar, S. (2001). Consumer rapport to luxury: Analyzing complex and ambivalent attitudes. Working Paper Series: CR 736/2001, Paris.

Dubois, B., \& Paternault, C. (1995). Observations: Understanding the world of international luxury brands: The 'dream formula'. Journal of Advertising Research, 35(4), 69-76.

Dwivedi, Y. K., Kapoor, K. K., \& Chen, H., (2015). Social media marketing and advertising. The Marketing Review, 15(3), 289-309. https://doi.org/10.1362/146934715X14441363377999

Essamri, A., McKechnie, S., \& Winklhofer, H. (2019). Co-creating corporate brand identity with online brand communities: A managerial perspective. Journal of Business Research, 96, 366-375. https://doi.org/10.1016/j.jbusres.2018.07.015

Facebook, Inc. (2018). Retrieved May 14, 2019, from https://s21.q4cdn.com/399680738/files/doc_financials/annual_reports/2018-Annual-Report.pdf

Felix, R., Rauschnabel, P. A., \& Hinsch, C. (2017). Elements of strategic social media marketing: A holistic framework. Journal of Business Research, 70, 118-126. https://doi.org/10.1016/j.jbusres.2016.05.001

Filo, K., Lock, D., \& Karg, A. (2015). Sport and social media research: a review. Sport Management Review, 18(2), 166-181. https://doi.org/10.1016/j.smr.2014.11.001

Gallaugher, J., \& Ransbotham, S. (2010). Social media and customer dialog management at Starbucks. MIS Quarterly Executive, 9(4), 197-212.

Gielens, K., \& Steenkamp, J. B. E. M. (2019). Branding in the era of digital (dis)intermediation. International Journal of Research in Marketing (in press). https://doi.org/10.1016/j.ijresmar.2019.01.005

Godey, B., Manthiou, A., Pederzoli, D., Rokka, J., Aiello, G., Donvito, R., \& Singh, R. (2016). Social media marketing efforts of luxury brands: Influence on brand equity and consumer behaviour. Journal of Business 
Research, 69(12), 5833-5841. https://doi.org/10.1016/j.jbusres.2016.04.181

Godey, B., Pederzoli, D., Aiello, G., Donvito, R., Chan, P., Oh, H., Singh, R., Skorobogatykh, I. I., Tsuchiya, J., ... Weitz, B. (2012). Brand and country-of-origin effect on consumers' decision to purchase luxury products. Journal of Business Research, 65(10), 1461-1470. https://doi.org/10.1016/j.jbusres.2011.10.012

Guido, G., De Matteis, C., Pino, G., \& Amatulli, C. (2017). Internalised and externalised luxury consumption: scale development and correlations with personality traits and negative values. International Marketing Trends Luxury Industries Conference, London (UK), 15-16 September 2017.

Gundecha, P., \& Liu, H. (2012). Mining social media: a brief introduction. New Directions in Informatics, Optimization, Logistics, and Production, 1-17. https://doi.org/10.1287/educ.1120.0105

Gurău, C. (2008). Integrated online marketing communication: implementation and management. Journal of Communication Management, 12, (2), 169-184. https://doi.org/10.1108/13632540810881974

Hagtveded, H., \& Patrick, V. (2009). The broad embrace of luxury: Hedonic potential as a driver of brand extendibility. Journal of Consumer Psychology, 19(4), 608-619. https://doi.org/10.1016/j.jcps.2009.05.007

Hamilton, M., Kaltcheva, V. D., \& Rohm, A. J. (2016). Social Media and Value Creation: The Role of Interaction Satisfaction and Interaction Immersion. Journal of Interactive Marketing, 36, 121-133. https://doi.org/10.1016/j.intmar.2016.07.001

Hansen, J., \& Wänke, M. (2011). The abstractness of luxury. Journal of Economic Psychology, 32(5), 789-796. https://doi.org/10.1016/j.joep.2011.05.005

He, J., \& Shao, B. (2018). Examining the dynamic effects of social network advertising: A semiotic perspective. Telematics and Informatics, 35(2), 504-516. https://doi.org/10.1016/j.tele.2018.01.014

Heine, K. (2010). The luxury brand personality traits (pp. 1-14). Thought leaders international conference in brand management.

Heine, K., \& Phan, M. (2011). Trading-up Mass-market Goods to Luxury Products. Australasian Marketing Journal, 19(2), 108-114. https://doi.org/10.1016/j.ausmj.2011.03.001

Hoffman, D. L., \& Novak, T. P. (1996). Marketing in Hypermedia Computer-Mediated Environments: Conceptual Foundations. Journal of Marketing, 60, 50-68. https://doi.org/10.2307/1251841

Hudders, L. (2012). Why the devil wears Prada: Consumers' purchase motives for luxuries. Journal of Brand Management, 19(7), 609-622. https://doi.org/10.1057/bm.2012.9

Hudders, L., Pandelaere, M., \& Vyncke, P. (2013). Consumer meaning making: The meaning of luxury brands in a democratised luxury world. International Journal of Market Research, 55(3), 391-412. https://doi.org/10.2501/IJMR-2013-036

Jacobson, J., Gruzd, A., \& Hernández-García, Á. (2019). "=Social media marketing: Who is watching the watchers? Journal of Retailing and Consumer Services (in Press). https://doi.org/10.1016/j.jretconser.2019.03.001

Jahn, B., Kunz, W., \& Meyer, A. (2012). The role of social media for luxury brands-Motives for consumer engagement and opportunities for business. Identitätsbasierte Luxusmarkenführung, 221-236. Springer Gabler, Wiesbaden. https://doi.org/10.1007/978-3-8349-4060-5_14

Jiménez-Zarco, A. I., Rospigliosi, A., Martínez-Ruiz, M. P., \& Izquierdo-Yusta, A. (2019). Marketing 4.0: enhancing consumer-brand engagement through big data analysis. In Web Services: Concepts, Methodologies, Tools, and Applications (pp. 2172-2195). IGI Global. https://doi.org/10.4018/978-1-5225-7501-6.ch113

Kapferer, J. N. (1997). Managing luxury brands. Journal of Brand Management, 4(4), 251-260. https://doi.org/10.1057/bm.1997.4

Kapferer, J. N., \& Bastien, V. (2015). Luxury strategy. Sovvertire le regole del marketing per costruire veri brand di lusso. Milan, FrancoAngeli.

Kapferer, J. N., \& Michaut, A. (2015). Luxury and sustainability: a common future? The match depends on how consumers define luxury. Luxury Research Journal, 1(1), 3-17. https://doi.org/10.1504/LRJ.2015.069828

Kapferer, J. N. M., \& Valette-Florence, P. (2018). The impact of increased brand penetration on luxury desirability: A dual effect. Journal of Brand Management, 25(5), 424-435. https://doi.org/10.1057/s41262-018-0091-7 
Kaplan, A. M., \& Haenlein, M. (2010). Users of the world, unite! The challenges and opportunities of social media. Business Horizons, 53(1), 59-68. https://doi.org/10.1016/j.bushor.2009.09.003

Kapoor, K. K., Tamilmani, K., Rana, N. P., Patil, P., Dwivedi, Y. K., \& Nerur, S. (2018). Advances in social media research: past, present and future. Information Systems Frontiers, 1-28. https://doi.org/10.1007/s10796-017-9810-y

Kastanakis, M. N., \& Voyer, B. G. (2014). The effect of culture on perception and cognition: A conceptual framework. Journal of Business Research, 67(4), 425-433. https://doi.org/10.1016/j.jbusres.2013.03.028

Keller, K. L. (2009). Managing the growth trade-off: Challenges and opportunities in luxury branding. Journal of Brand Management, 16(5-6), 290-301. https://doi.org/10.1057/bm.2008.47

Kelly, L., Kerr, G., \& Drennan, J. (2010). Avoidance of advertising in social networking sites: The teenage $\begin{array}{lllll}\text { perspective. Journal of Interactive } & \text { Advertising, }\end{array}$ https://doi.org/10.1080/15252019.2010.10722167

Key, T. M., \& Czaplewski, A. J. (2017). Upstream social marketing strategy: An integrated marketing $\begin{array}{llll}\text { communications } \quad \text { approach. } & \text { Business }\end{array}$ https://doi.org/10.1016/j.bushor.2017.01.006

Kietzmann, J. H., Hermkens, K., McCarthy, I. P., \& Silvestre, B. S. (2011). Social media? Get serious! Understanding the functional building blocks of social media. Business Horizons, 54(3), 241-251. https://doi.org/10.1016/j.bushor.2011.01.005

Kim, A. J. Y., \& Ko, E. J. (2010). The impact of design characteristics on brand attitude and purchase intention-focus on luxury fashion brands. Journal of the Korean Society of Clothing and Textiles, 34(2), 252-265. https://doi.org/10.5850/JKSCT.2010.34.2.252

Kim, A. J. Y., \& Ko, E. J. (2012). Do social media marketing activities enhance customer equity? An empirical study of luxury fashion brand. Journal of Business Research, 65(10), 1480-1486. https://doi.org/10.1016/j.jbusres.2011.10.014

Kim, J., \& Lee, K. H. (2019). Influence of integration on interactivity in social media luxury brand communities. Journal of Business Research, 99, 422-429. https://doi.org/10.1016/j.jbusres.2017.10.001

Kim, J., Spielmann, N., \& McMillan, S. J. (2012). Experience effects on interactivity: Functions, processes, and $\begin{array}{llll}\text { perceptions. Journal of } & \text { Business }\end{array}$ https://doi.org/10.1016/j.jbusres.2011.02.038

Ko, E., Costello, J. P., \& Taylor, C. R. (2019). What is a luxury brand? A new definition and review of the literature. Journal of Business Research, 99, 405-413. https://doi.org/10.1016/j.jbusres.2017.08.023

Kohli, C., Suri, R., \& Kapoor, A. (2015). Will social media kill branding? Business Horizons, 58(1), 35-44. https://doi.org/10.1016/j.bushor.2014.08.004

Koivisto, E., \& Mattila, P. (2018). Extending the luxury experience to social media-User-Generated Content co-creation in a branded event. Journal of Business Research, 1-9. https://doi.org/10.1016/j.jbusres.2018.10.030

Kotler, P., Kartajaya, H., \& Setawan, I. (2010). Marketing 4.0: From Products to Customers to the Human Spirit. Hoboken, New Jersey: John Wiley \& Sons, Inc. https://doi.org/10.1002/9781118257883

Kotler, P., Kartajaya, H., \& Setawan, I. (2017). Marketing 4.0: Moving from Traditional to Digital. Hoboken, New Jersey: John Wiley \& Sons, Inc.

Kumar, V., Choi, J. B., \& Greene, M. (2017). Synergistic effects of social media and traditional marketing on brand sales: capturing the time-varying effects. Journal of the Academy of Marketing Science, 45(2), 268-288. https://doi.org/10.1007/s11747-016-0484-7

Labrecque, L. I. (2014). Fostering consumer-brand relationships in social media environments: the role of parasocial interaction. Journal of Interactive Marketing, 28, 134-148. https://doi.org/10.1016/j.intmar.2013.12.003

Leibenstein, H. (1950). Bandwagon, snob, and Veblen effects in the theory of consumers' demand. Quarterly Journal of Economics, 64(2), 183-207. https://doi.org/10.2307/1882692

Leonardi, P. M., Huysman, M., \& Steinfield, C. (2013). Enterprise social media: Definition, history, and prospects for the study of social technologies in organizations. Journal of Computer-Mediated 
Communication, 19(1), 1-19. https://doi.org/10.1111/jcc4.12029

Li, C., \& Bernoff, J. (2008). Groundswell: Winning in a World Transformed by Social Technologies. Boston: Harvard Business Press.

Lim, Y., Chung, Y., \& Weaver, P. A. (2012). The impact of social media on destination branding: Consumer-generated videos versus destination marketer-generated videos. Journal of Vacation Marketing, 18(3), 197-206. https://doi.org/10.1177/1356766712449366

Lipovetsky, G., \& Roux E. (2003). Le Luxe Éternel: De l’Âge du Sacré au Temps des Marques. Editions Gallimard, Paris.

Maman, L. A.-F., \& Kourdoughli, A. (2014). The e-semiotics of luxury. Journal of Global Fashion Marketing, 5(3), 197-208. https://doi.org/10.1080/20932685.2014.906120

Martín-Consuegra, D., Díaz, E., Gómez, M., \& Molina, A. (2019). Examining consumer luxury brand-related behavior intentions in a social media context: The moderating role of hedonic and utilitarian motivations. Physiology \& Behavior, 200, 104-110. https://doi.org/10.1016/j.physbeh.2018.03.028

Mortelmans, D. (2005). Sign values in processes of distinction: The concept of luxury. Semiotica, 2005(157), 497-520. https://doi.org/10.1515/semi.2005.2005.157.1-4.497

Müller-Stewens, G., \& Berghaus, B. (2014). The market and business of luxury: an introduction. In B. Berghaus, G. Müller-Stewens \& S. Reinecke (Eds.), The management of luxury (pp. 3-25). A practitioner's handbook. Kogan Page, London.

Mundel, J., Huddleston, P., \& Vodermeier, M. (2017). An exploratory study of consumers' perceptions: What are affordable luxuries? Journal of Retailing and Consumer Services, 35, 68-75. https://doi.org/10.1016/j.jretconser.2016.12.004

Naatu, F. (2016). Brand building for competitive advantage in the Ghanaian jewelry industry. International Review of Management and Marketing, 6(3), 551-558.

Nguyen, B., Yu, X., Melewar, T. C., \& Chen, J. (2015). Brand innovation and social media: Knowledge acquisition from social media, market orientation, and the moderating role of social media strategic capability. Industrial Marketing Management, 51, 11-25. https://doi.org/10.1016/j.indmarman.2015.04.017

Nia, A., \& Lynne, Z. J. (2000). Do counterfeits devalue the ownership of luxury brands? Journal of Product \& Brand Management, 9(7), 485-497. https://doi.org/10.1108/10610420010351402

Nueno, J. L., \& Quelch, J. (1998). The mass marketing of luxury. Business Horizons, 41(6), 61-68. https://doi.org/10.1016/S0007-6813(98)90023-4

Obar, J. A. \& Wildman, S. (2015). Social media definition and the governance challenge: An introduction to the special issue. Telecommunications Policy, 39(9), 745-750. https://doi.org/10.1016/j.telpol.2015.07.014

Okazaki, S., \& Taylor, C. R. (2013). Social media and international advertising: theoretical challenges and future directions. International Marketing Review, 30(1), 56-71. https://doi.org/10.1108/02651331311298573

Okonkwo, U. (2007). Luxury Fashion Branding. Palgrave Macmillan, Londra. https://doi.org/10.1057/9780230590885

Okonkwo, U. (2009). Sustaining the luxury brand on the Internet. Journal of Brand Management, 16(5-6), 302-310. https://doi.org/10.1057/bm.2009.2

Ozuem, W., Howell, K. E., \& Lancaster, G. (2008). Communicating in the new interactive marketspace. European Journal of Marketing, 42(9/10), 1059-1083. https://doi.org/10.1108/03090560810891145

Palla, P. J., Tsiotsou, R. H., \& Zotos, Y. C. (2013). Is website interactivity always beneficial? An elaboration likelihood model approach. Advertising Research, 4, 131-145. https://doi.org/10.1007/978-3-658-02365-2_10

Pantano, E., Passavanti, R., Priporas, C-V., \& Verteramo, S. (2018). To what extent luxury retailing can be smart? Journal of Retailing and Consumer Services, 43, 90-100. https://doi.org/10.1016/j.jretconser.2018.03.012

Pastore, A., \& Vernuccio, M. (2008). Impresa e comunicazione. Principi e strumenti per il management. Apogeo Editore.

Patel, K. (2013). Incremental journey for World Wide Web: Introduced with Web 1.0 to recent Web 5.0-A survey paper. International Journal of Advanced Research in Computer Science and Software Engineering, 
$3(10), 410-417$.

Phan, M., Thomas, R., \& Heine, K. (2011). Social media and luxury brand management: The case of Burberry. Journal of Global Fashion Marketing, 2(4), 213-222. https://doi.org/10.1080/20932685.2011.10593099

Phau, I., \& Prendergast, G. (2000). Consuming luxury brands: The relevance of the Rarity Principle. Brand Management, 8(2), 122-138. https://doi.org/10.1057/palgrave.bm.2540013

Prentice, C., \& Loureiro, S. M. C. (2018). Consumer-based approach to customer engagement-The case of luxury brands. Journal of Retailing and Consumer Services, 43, 325-332. https://doi.org/10.1016/j.jretconser.2018.05.003

Rapp, A., Beitelspacher, L., Grewal, D., \& Hughes, D. (2013). Understanding social media effects across seller, retailer, and consumer interactions. Journal of the Academy of Marketing Science, 41(5), 547-566. https://doi.org/10.1007/s11747-013-0326-9

Richeter, A., \& Koch, M. (2007). Social software-status quo und Zukunft. Technischer Bericht, Nr. 2007-01, Fakultät für Informatik. Universität der Bundeswehr, Monaco.

Roux, E. (1991). Comment se positionnent les marques de luxe? Revue Française du Marketing, 132/133(2-3), $111-118$.

Roux, E., Tafani, E., \& Vigneron, F. (2017). Values associated with luxury brand consumption and the role of gender. Journal of Business Research, 71, 102-113. https://doi.org/10.1016/j.jbusres.2016.10.012

Royle, J., \& Laing, A. (2014). The digital marketing skills gap: Developing a Digital Marketer Model for the communication industries. International Journal of Information Management, 34(2), 65-73. https://doi.org/10.1016/j.ijinfomgt.2013.11.008

Russo, A., Watkins, J., Kelly, L., \& Chan, S. (2008). Participatory communication with social media. Curator: The Museum Journal, 51(1), 21-31. https://doi.org/10.1111/j.2151-6952.2008.tb00292.x

Salo, J. (2017). Social media research in the industrial marketing field: Review of literature and future research directions. Industrial Marketing Management, $115-129$. https://doi.org/10.1016/j.indmarman.2017.07.013

Stankevich, A., (2017). Explaining the Consumer Decision-Making Process: Critical Literature Review. Journal of International Business Research and Marketing, 2(6), 7-14. https://doi.org/10.18775/jibrm.1849-8558.2015.26.3001

Stathopoulou, A., \& Balabanis, G. (2019). The effect of cultural value orientation on consumers' perceptions of luxury value and proclivity for luxury consumption. Journal of Business Research, 102, 298-312. https://doi.org/10.1016/j.jbusres.2019.02.053

Sung, Y., Choi, S. M., Ahn, H., \& Song, Y. A. (2015). Dimensions of luxury brand personality: Scale development and validation. Psychology \& Marketing, 32(1), 121-132. https://doi.org/10.1002/mar.20767

Tavakoli, R., \& Wijesinghe, S. N. R (2019). The evolution of the web and netnography in tourism: A systematic review. Tourism Management Perspectives, 29, 48-55. https://doi.org/10.1016/j.tmp.2018.10.008

The Boston Consulting Group-Fondazione Altagamma. (2019). True - Luxury Global Consumer Insight. 6th Edition Milano, April 17th 2019. Retrieved June 10, 2019, from http://media-publications.bcg.com/france/True-Luxury\%20Global\%20Consumer\%20Insight\%202019\%20\%20Plenary\%20-\%20vMedia.pdf

Tranfield, D., Denyer, D., \& Smart, P. (2003). Towards a Methodology for Developing Evidence-Informed Management Knowledge by Means of Systematic Review. British Journal of Management, 14, 207-222. https://doi.org/10.1111/1467-8551.00375

Truong, Y., McColl, R., \& Kitchen, P. (2010). Practitioners' perceptions of advertising strategies for digital media. International Journal of Advertising, 29(5), 709-725. https://doi.org/10.2501/S0265048710201439

Tuten, T. L., \& Solomon, M. R. (2017). Social Media Marketing. Sage.

Veblen, T. (1899). The Theory of the Leisure Class. New York, The MacMillan Company.

Vendemia, M. A. (2017). When do consumers buy the company? Perceptions of interactivity in company-consumer interactions on social networking sites. Computers in Human Behavior, 71, 99-109. https://doi.org/10.1016/j.chb.2017.01.046 
Vernuccio, M., \& Ceccotti, F. (2015). Strategic and organisational challenges in the integrated marketing communication paradigm shift: A holistic vision. European Management Journal, 33(6), 438-449. https://doi.org/10.1016/j.emj.2015.09.001

Vickers, J. S., \& Renand, F. (2003). The marketing of luxury goods: an exploratory study-three conceptual dimensions. The Marketing Review, 3(4), 459-478. https://doi.org/10.1362/146934703771910071

Vigneron, F., \& Johnson, L. W. (1999). Review and a conceptual framework of prestige-seeking consumer behaviour. Academy of Marketing Science Review, 99(1), 1-15.

Vigneron, F., \& Johnson, L. W. (2004). Measuring perceptions of brand luxury. Brand Management, 11(6), 484-506. https://doi.org/10.1057/palgrave.bm.2540194

Wang, X., Yu, C., \& Wei, Y. (2012). Social Media Peer Communication and Impacts on Purchase Intentions: A Consumer Socialization Framework. Journal of Interactive Marketing, 26(4), 198-208. https://doi.org/10.1016/j.intmar.2011.11.004

Wells, W. H. (2011). Social media and social networking: What's the difference? Retrieved November 12, 2018, from http://www.williamhwells.com/2011/06/18/social-media-and-social-networking-whats-the-difference/

Wiedmann, K., Hennigs, N., \& Siebels, A. (2007). Measuring Consumers' Luxury Value Perception: A Cross-Cultural Framework. Academy of Marketing Science Review, 7, 1-21.

Wiedmann, K., Hennigs, N., \& Siebels, A. (2009). Value-Based Segmentation of Luxury Consumption Behavior. Psychology \& Marketing, 26(7), 625-651. https://doi.org/10.1002/mar.20292

Xiang, Z., \& Gretzel, U. (2010). Role of social media in online travel information search. Tourism Management, 31(2), 179-188. https://doi.org/10.1016/j.tourman.2009.02.016

Yeh, C. H., Wang, Y. S., \& Yieh, K. (2016). Predicting smartphone brand loyalty: Consumer value and consumer-brand identification perspectives. International Journal of Information Management, 36(3), 245-257. https://doi.org/10.1016/j.ijinfomgt.2015.11.013

Yeoman, I. (2011). The changing behaviours of luxury consumption. Journal of Revenue and Pricing Management, 10(1), 47-50. https://doi.org/10.1057/rpm.2010.43

Yeoman, I., \& McMahon-Beattie, U. (2006). Luxury markets and premium pricing. Journal of Revenue and Pricing Management, 4(4), 319-328. https://doi.org/10.1057/palgrave.rpm.5170155

Yu, U. J., Cho, E., \& Johnson, K. K.P. (2017). Effects of brand familiarity and brand loyalty on imagery elaboration in online apparel shopping. Journal Global Fashion Marketing, 8, 193-206. https://doi.org/10.1080/20932685.2017.1284603

Zembik, M. (2014). Social media as a source of knowledge for customers and enterprises. Online Journal of Applied Knowledge Management, 2(2), 132-148.

Zhu, Z., Wang, J., Wang, X., \& Wan, X. (2016). Exploring factors of user's peer-influence behavior in social media on purchase intention: Evidence from QQ. Computers in Human Behavior, 63, 980-987. https://doi.org/10.1016/j.chb.2016.05.037

\section{Appendix A}

\section{Summary of the Main Papers Analysed}

\begin{tabular}{|c|c|c|c|c|}
\hline Authors - Paper & Search & Methodology & Variables/topics & Results \\
\hline $\begin{array}{l}\text { Amatulli, C. \& } \\
\text { Guido, G. (2010). } \\
\text { Determinants of } \\
\text { purchasing } \\
\text { intention for } \\
\text { fashion luxury } \\
\text { goods in the Italian } \\
\text { market - A } \\
\text { laddering approach. }\end{array}$ & $\begin{array}{l}\text { Empirical } \\
\text { research }\end{array}$ & $\begin{array}{l}\text { Qualitative analysis based on } \\
\text { the application of the } \\
\text { Laddering and the Means-End } \\
\text { Chain (MEC) technique. A } \\
\text { content analysis was carried on } \\
\text { basis to level of the attributes, } \\
\text { consequences and values: } \\
\text { concrete attributes; abstract } \\
\text { attributes; functional } \\
\text { consequences; psychological } \\
\text { consequences; functional } \\
\text { values; terminal values. } \\
\text { Finally, a hierarchical value } \\
\text { map (HVM) it was elaborated, }\end{array}$ & $\begin{array}{l}\text { The general structure of the } \\
\text { Means-End Chain used in } \\
\text { each interview was: } \\
\text { Attributes associated with } \\
\text { the luxury brand --> } \\
\text { Meanings of these } \\
\text { attributes and consequences } \\
\text { of these meanings for the } \\
\text { client -> Values of these } \\
\text { consequences for the client } \\
\text { and personal ends. }\end{array}$ & $\begin{array}{l}\text { The study has obtained and } \\
\text { codified } 45 \text { constructs: } 21 \\
\text { attributes ( } 11 \text { concrete and } 10 \\
\text { abstract), } 12 \text { consequences (one } \\
\text { functional and } 11 \text { psychological) } \\
\text { and } 12 \text { values (four instrumental } \\
\text { and eight terminals). The results of } \\
\text { the study may be of interest to } \\
\text { marketing managers who manage } \\
\text { communication or advertising in } \\
\text { luxury fashion companies and wish } \\
\text { to focus on the fundamental values } \\
\text { of consumers. Finally, this research } \\
\text { contributes to literature by }\end{array}$ \\
\hline
\end{tabular}


to illustrate the relationships

between attributes initially

identified up to make identify a

luxurious hierarchical map of

values (LHVM) which outlines

the aspirations linked to

luxury.

Kim, A. J. \& Ko,
(2012). Do social
media marketing

media marketing

customer equity?

An empirical study

brand.
The methodology using in this research four steps followed: preliminary tests, measurements, sample selection and data collection and data analysis. of luxury fashion

verifying that product quality and internal motivation, rather than ostentation and status symbol, are key factors in influencing the purchase of luxury fashion goods purchased in the mature Italian market.

The results of this research show

- value equity, that the analyzed sample is a "real" consumer of luxury goods; furthermore, there is a low percentage of consumers over 40 (9\%). As for the SMM activities of a luxury brand, these offer a variety of free content and possibility to do the search for personalized information, generating an interaction between users who generate a positive WOM.

\begin{tabular}{|c|c|c|c|}
\hline $\begin{array}{l}\text { Amatulli, C. \& } \\
\text { Guido, G (2012). } \\
\text { Externalised vs. } \\
\text { internalised } \\
\text { consumption of } \\
\text { luxury goods: } \\
\text { propositions and } \\
\text { implications for } \\
\text { luxury retail } \\
\text { marketing. }\end{array}$ & $\begin{array}{l}\text { Literature } \\
\text { review }\end{array}$ & $\begin{array}{l}\text { Qualitative analysis of the } \\
\text { most important contributions } \\
\text { on the existing dichotomies } \\
\text { relative the consumption of } \\
\text { luxury goods. }\end{array}$ & $\begin{array}{l}\text { Six dimensions: for } \\
\text { Externalised luxury, } \\
\text { ostentation, materialism } \\
\text { and superfluity; for } \\
\text { internalized luxury we } \\
\text { consider the individual } \\
\text { lifestyle, the emotions / } \\
\text { hedonism and culture }\end{array}$ \\
\hline $\begin{array}{l}\text { Godey, B., } \\
\text { Manthiou, A., } \\
\text { Pederzoli, D., } \\
\text { Rokka, J., Aiello G., } \\
\text { Donvito, R. e } \\
\text { Singh, R. (2016). } \\
\text { Social media } \\
\text { marketing efforts of } \\
\text { luxury brands: } \\
\text { Influence on brand }\end{array}$ & $\begin{array}{l}\text { Empirical } \\
\text { research }\end{array}$ & $\begin{array}{l}\text { Submission a questionnaire to } \\
\text { a sample of } 845 \text { respondents } \\
\text { from } 4 \text { different countries with } \\
\text { the aim of investigating on the } \\
\text { influence of social media } \\
\text { marketing activities on the } \\
\text { creation of brand equity and on } \\
\text { the consumer behavior analisys } \\
\text { in a luxury brands context } \\
\text { (analysis of } 5 \text { brand). }\end{array}$ & $\begin{array}{l}\text { The variables using for the } \\
\text { creation of the } \\
\text { questionnaire: the average } \\
\text { annual expenditure on } \\
\text { luxury goods and the time } \\
\text { spent weekly on social } \\
\text { media. } 5 \text { perspectives } \\
\text { considered: entertainment, } \\
\text { interaction, trendiness, } \\
\text { customization and WOM }\end{array}$ \\
\hline
\end{tabular}
been outlined which could represent a fundamental starting point for the realization of the best retail strategies, especially in the fashion luxury industry.

These prospects positively effect on the achievement of a profitable to brand and to her dimensions, such as brand awareness and brand image.

\begin{tabular}{|c|c|c|}
\hline $\begin{array}{l}\text { Definition of } \\
\text { the } \\
\text { theoretical } \\
\text { framework } \\
\text { and } \\
\text { empirical } \\
\text { research }\end{array}$ & $\begin{array}{l}\text { The study on a sample of } 125 \\
\text { students born in the } 90 \text { s was } \\
\text { conducted. Participants } \\
\text { completed a survey to measure } \\
\text { customer value twice: before } \\
\text { and after the diary period }\end{array}$ & $\begin{array}{l}\text { Satisfaction } \\
\text { (interaction), } \\
\text { - Immersion } \\
\text { (interaction), } \\
-\quad \text { Customer lifetime } \\
\text { value (CLV), } \\
-\quad \text { Customer influence } \\
\text { value (CIV), } \\
-\quad \text { Customer knowledge } \\
\text { value (CKV). }\end{array}$ \\
\hline
\end{tabular}

Comparing the size of the standardized effects showed that, for all significant relationships, the linear effects were approximately 1 to 2 times larger than the corresponding interception effect, suggesting the importance of the direction and the rate of change over time both in terms of satisfaction and immersion. The results of a second sample of the same population have shown that the results cannot be explained by a simple measurement effect.

\begin{tabular}{|c|c|c|c|c|}
\hline $\begin{array}{l}\text { Ko, E., Costello, J. } \\
\text { P. \& Taylor, C. R. } \\
\text { (2019). What is a } \\
\text { luxury brand? A } \\
\text { new definition and } \\
\text { review of the } \\
\text { literature. }\end{array}$ & $\begin{array}{l}\text { Literature } \\
\text { review }\end{array}$ & $\begin{array}{l}\text { Research of academic papers } \\
\text { using keywords and } \\
\text { identification of over } 130 \\
\text { articles that analyze the issue } \\
\text { of luxury marketing }\end{array}$ & $\begin{array}{l}\text { Three basic construct to } \\
\text { outline a univocal } \\
\text { definition of the concept of } \\
\text { luxury brand: a solid } \\
\text { conceptual basis, broad } \\
\text { applicability to luxury } \\
\text { brands in general and not } \\
\text { only to a subset as just } \\
\text { products or services, } \\
\text { operativity able to measure } \\
\text { the construct }\end{array}$ & $\begin{array}{l}\text { A theoretical framework has been } \\
\text { defined used in the research on } \\
\text { luxury brand and the results are } \\
\text { relevant to the status and values of } \\
\text { luxury, to the behavior of the } \\
\text { luxury consumer and to the } \\
\text { management of the luxury brand. }\end{array}$ \\
\hline
\end{tabular}




\begin{tabular}{|c|c|c|c|}
\hline $\begin{array}{l}\text { Salo, J. (2017). } \\
\text { Social media } \\
\text { research in the } \\
\text { industrial } \\
\text { marketing field: } \\
\text { Review of literature } \\
\text { and future research } \\
\text { directions. }\end{array}$ & $\begin{array}{l}\text { Literature } \\
\text { review }\end{array}$ & $\begin{array}{l}\text { Systematic review of the } \\
\text { literature divided into three } \\
\text { phases: planning, analysis and } \\
\text { comments on the analyzed } \\
\text { contributions. } 40 \text { documents of } \\
\text { international importance was } \\
\text { be analizated. }\end{array}$ & $\begin{array}{l}\text { Advertising, buyer-seller } \\
\text { relationships and corporate } \\
\text { networks, computers in } \\
\text { corporate marketing, } \\
\text { decision support and } \\
\text { management sciences, } \\
\text { marketing and other } \\
\text { functions, marketing } \\
\text { communication, sales and } \\
\text { public relations }\end{array}$ \\
\hline
\end{tabular}

\begin{tabular}{|c|c|}
\hline $\begin{array}{l}\text { Felix, R., } \\
\text { Rauschnabel, P. A. } \\
\text { \& Hinsch, C. } \\
\text { (2017). Elements of } \\
\text { strategic social } \\
\text { media marketing: A } \\
\text { holistic framework. }\end{array}$ & $\begin{array}{l}\text { Definition of } \\
\text { the } \\
\text { theoretical } \\
\text { framework } \\
\text { and } \\
\text { empirical } \\
\text { research }\end{array}$ \\
\hline
\end{tabular}

Qualitative-quantitative study defined in three phases. The first two phases define the sample. In phase two, the sample consisted of $265 \mathrm{SMM}$ experts, of whom only 50 responded positively to the survey sent by e-mail. Data analysis through a coding process.
Job position, work experience and direct exposure to SMM practices in real contexts of the sector.
Today the focus shifts from the optimization of the individual social media channels towards a broader view of the analysis of the evaluation and measurement of performance. These measures will have to be adopted with more tools through a true marketing automation with web data analysis and other types of digital analysis to better manage sales, brand awareness marketing units, customer service or advertising in different contexts industrial.

The results of this study reveal four interdependent dimensions of social media marketing that companies should address when they conceptualize or manage their strategic marketing approach on social media. Furthermore, this research suggests a new definition of social media marketing that includes the 4 dimensions found in the study

\begin{tabular}{|c|c|c|c|}
\hline $\begin{array}{l}\text { Alalwan, A. A., } \\
\text { Rana, N. P. } \\
\text { Dwivedi, Y. K. \& } \\
\text { Algharabat, R. } \\
\text { (2017). Social } \\
\text { media in } \\
\text { marketing: A } \\
\text { review and analysis } \\
\text { of the existing }\end{array}$ & $\begin{array}{l}\text { Literature } \\
\text { review }\end{array}$ & $\begin{array}{l}\text { Selection and study of } 144 \\
\text { marketing paper in the social } \\
\text { media field between september } \\
2015 \text { and january } 2016\end{array}$ & $\begin{array}{l}\text { 7 main topics: } \\
\text { - } \quad \text { advertising, } \\
\text { - } \\
\text { - } \\
\text { - } \quad \text { CRM, } \\
\text { - } \quad \text { branding, } \\
\text { - } \quad \text { consumer behavior, } \\
\text { - } \quad \text { organizations' } \\
\text { prospects }\end{array}$ \\
\hline
\end{tabular}

literature.

Telematics and

Informatics

Wang, Z. \& Kim,

H. G. (2017). Can

Social Media

Marketing Improve

Customer

Relationship

$\begin{array}{ll}\begin{array}{l}\text { Definition of } \\ \text { the }\end{array} & \begin{array}{l}\text { Empirical study based on the } \\ \text { development of a conceptual }\end{array} \\ \text { theoretical } & \text { model that establishes the } \\ \text { framework } & \text { relationship between the social } \\ \text { and } & \text { CRM functionalities and the }\end{array}$

client's commitment

considering how these

functionalities directly

influence company

performance. The data on one

of the first social media sites

was collected: Facebook. The

final sample consisted of 232

companies.
This problem is developing more and more quickly, it is necessary that the research focuses on how the phenomenon of marketing can behave differently from one platform to another, especially depending on the different countries considered, they are developed, emerging or in development path or according to different cultures and contexts

\begin{tabular}{|c|c|}
\hline $\begin{array}{l}\text { Use of social media, } \\
\text { Customer engagement, } \\
\text { Social CRM functionality. } \\
\text { Tobin's q was used as the } \\
\text { study-dependent variable. } \\
\text { Control variables: using the } \\
\text { corresponding company } \\
\text { indices each year from } \\
2004 \text { to } 2014 \text { as a measure } \\
\text { of customer satisfaction. } \\
\text { other variables: Company } \\
\text { performance, Year Use of } \\
\text { social media, Engagement. } \\
\text { Customer, Balances, } \\
\text { Employee Financial } \\
\text { Leverage and Customer } \\
\text { Satisfaction }\end{array}$ & $\begin{array}{l}\text { The results of the correlation } \\
\text { matrix indicate that the social } \\
\text { CRM capacity is positively } \\
\text { correlated to Tobin's q and the } \\
\text { client's commitment is positively } \\
\text { correlated to Tobin's q. Four } \\
\text { conditions were tested that should } \\
\text { be met to verify the mediation } \\
\text { effect: } 1 \text {. Social CRM features. } 2 \text {. } \\
\text { The ability of social CRM. } 3 \text {. } \\
\text { Customer commitment. } 4 \text {. } \\
\text { performance of the company. }\end{array}$ \\
\hline $\begin{array}{l}\text { - } \\
\text { - } \quad \text { discomfort, } \\
\text { - } \quad \text { guilt, } \\
\text { - } \quad \text { social value, } \\
\text { - } \quad \text { knorchase, } \\
\text { - } \quad \text { influence, } \\
\text { - } \quad \text { reference } \\
\text { - } \\
\text { well-being. }\end{array}$ & $\begin{array}{l}\text { The results of the model adaptation } \\
\text { indexes are acceptable. The results } \\
\text { of the standardized residual } \\
\text { co-variances and of the change } \\
\text { index values indicate that no } \\
\text { significant changes have been } \\
\text { made to the model. The mean } \\
\text { variance extracted for each } \\
\text { variable was greater than 50, } \\
\text { indicative of an adequate } \\
\text { convergence (Fornell \& Larcker, } \\
\text { 1981). Composite reliability was } \\
\text { acceptable for each of the factors. }\end{array}$ \\
\hline
\end{tabular}




\begin{tabular}{|c|c|c|}
\hline $\begin{array}{l}\text { Pantano, E., } \\
\text { Passavanti, R., } \\
\text { Priporas, C-V. \& } \\
\text { Verteramo, S. } \\
\text { (2018). To what } \\
\text { extent luxury } \\
\text { retailing can be } \\
\text { smart? }\end{array}$ & $\begin{array}{l}\text { Exploratory } \\
\text { research, } \\
\text { empirical } \\
\text { and } \\
\text { literature } \\
\text { review }\end{array}$ & $\begin{array}{l}\text { Exploratory study of an } \\
\text { emerging phenomenon. Five } \\
\text { luxury retail case studies were } \\
\text { selected ( } 3 \text { cases on fashion, } 1 \\
\text { accessories and } 1 \text { on the sale of } \\
\text { private jets). Data collection on } \\
\text { a sample of } 17 \text { respondents } \\
\text { including face-to-face } \\
\text { interviews with innovation } \\
\text { managers or digital marketing } \\
\text { strategies. the interview } \\
\text { included two main sections: } \\
\text { the effective or desired } \\
\text { integration of innovation in } \\
\text { marketing strategies and the } \\
\text { motivation that pushed the } \\
\text { company to innovate. }\end{array}$ \\
\hline
\end{tabular}

Presence of an office or

department of digital

marketing or an innovation

department. The main

organizational processes

considered are: ad hoc

capacity building, changes

in knowledge management

and creation of smart

partnerships; while sales

activities were divided into:

access to the product /

service, relations with the

sellers and consumption of

products / services
The results of this research state that smart technology for luxury retailing would have an average of 3 (moderate) on all components for the organizational process and sales activities. As none of the investigated companies is indeed strongly influencing all components of intelligent retailing, it is assumed that smart retailing is suitable but not yet adopted, due to the lack of intelligent technologies that influence (by improving) sales activities and the organizational process. It also contributes to literature on the luxury retail experience. Furthermore, the results reveal the great use of social media by luxury retailers as the main technology to improve management, while the adoption of mobile apps or interactive technologies is still limited

\begin{tabular}{|c|c|c|c|}
\hline $\begin{array}{l}\text { Alalwan, A. A. } \\
\text { (2018). } \\
\text { Investigating the } \\
\text { impact of social } \\
\text { media advertising } \\
\text { features on } \\
\text { customer purchase } \\
\text { intention, } \\
\text { International }\end{array}$ & $\begin{array}{l}\text { Definition of } \\
\text { the } \\
\text { theoretical } \\
\text { framework } \\
\text { and } \\
\text { empirical } \\
\text { research }\end{array}$ & $\begin{array}{l}\text { Quantitative study conducted } \\
\text { with an autarkic questionnaire } \\
\text { to collect data from a sample } \\
\text { of Jordanian customers using } \\
\text { social media platforms. data } \\
\text { were collected in the period } \\
\text { between July and October } \\
2017 \text { in four cities in Jordan } \\
\text { (Amman, Irbid, Zarqa and }\end{array}$ & $\begin{array}{l}\text { The conceptual model } \\
\text { based on three variables: } \\
\text { performance expectancy, } \\
\text { hedonistic motivation and } \\
\text { habit as well as } \\
\text { interactivity, information } \\
\text { and perceived relevance. } \\
\text { purchase intentions are also } \\
\text { considered. }\end{array}$ \\
\hline
\end{tabular}

Journal of

Information

Management
The results of this study amply support the importance of the role of perceived relevance to customers' buying intentions. This implies that if customers have the feeling that social media ads are related to their preferences and interests, they will be more inclined to buy products presented in social media ads. Balqa). The Likert seven-point scale was used to measure the items in the questionnaire. Of the 600 targeted participants, 437 completed the questionnaire and their answers were valid.

\begin{tabular}{|c|c|c|c|c|}
\hline $\begin{array}{l}\text { Kim, J. \& Lee, } \\
\text { K.H. (2019). } \\
\text { Influence of } \\
\text { integration on } \\
\text { interactivity in } \\
\text { social media luxury } \\
\text { brand communities. } \\
\text { Journal of Business } \\
\text { Research }\end{array}$ & $\begin{array}{l}\text { Empirical } \\
\text { research }\end{array}$ & $\begin{array}{l}\text { Quail-quantitative analysis } \\
\text { through the submission of a } \\
\text { questionnaire to a sample of } \\
252 \text { members of a luxury brand } \\
\text { communities in the South } \\
\text { Korean area. A structural } \\
\text { equation model was used to } \\
\text { analyze the collected data and } \\
\text { evaluate the validity / } \\
\text { reliability of the } \\
\text { measurements. }\end{array}$ & $\begin{array}{l}\text { - } \text { Integration, } \\
\text { - } \quad \text { interaction as a } \\
\text { process, } \\
\text { - } \quad \text { perceived } \\
\text { interactivity, } \\
\text { - } \quad \text { attitude, } \\
\text { - } \quad \text { purchase intention } \\
\text { brand loyalty. }\end{array}$ & $\begin{array}{l}\text { The model used in the present } \\
\text { research has shown the positivity } \\
\text { of the variables used, such as } \\
\text { integration and interaction, as well } \\
\text { as providing three key } \\
\text { contributions that have } \\
\text { implications for academics and } \\
\text { professionals such as a theoretical } \\
\text { framework for analyzing luxury } \\
\text { brand communies on social media } \\
\text { through the variables above and } \\
\text { the positive relations between } \\
\text { them. Finally, the study identifies } \\
\text { the effects of social media on the } \\
\text { interactivity of luxury brand } \\
\text { communies on attitude, brand } \\
\text { loyalty, and purchase intentions }\end{array}$ \\
\hline
\end{tabular}

\section{Copyrights}

Copyright for this article is retained by the author, with first publication rights granted to the journal.

This is an open-access article distributed under the terms and conditions of the Creative Commons Attribution license (http://creativecommons.org/licenses/by/4.0/). 